\title{
Global Imbalances or Bad Accounting? The Missing Dark Matter in the Wealth of Nations
}

\author{
Ricardo Hausmann and Federico Sturzenegger
}

CID Working Paper No. 124

January 2006

(C) Copyright 2006 Ricardo Hausmann, Federico Sturzenegger, and the President and Fellows of Harvard College

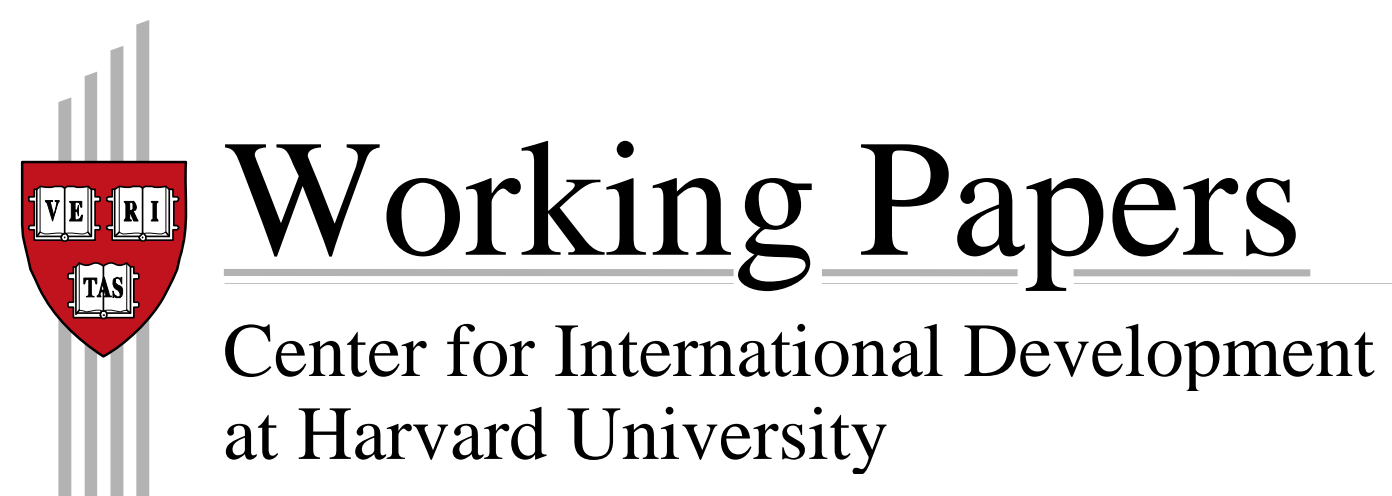




\title{
Global Imbalances or Bad Accounting? The Missing Dark Matter in the Wealth of Nations
}

\author{
Ricardo Hausmann and Federico Sturzenegger
}

Revised September 2006

\begin{abstract}
This paper argues that current account statistics may provide a poor indication for the real evolution of a country's net foreign assets. This may be due to a series of factors including the mismeasurement of FDI, unreported trade of insurance or liquidity services and debt relief. Because of these problems we suggest estimating net foreign assets by capitalizing the net investment income and then estimating the current account from the changes in this stock of foreign assets. We call dark matter the difference between our measure of net foreign assets and that portrayed by official statistics. We find dark matter to be important for many countries and that it relates to FDI flows, domestic volatility, and debt relief. We also find that, once dark matter is taken into account, global net asset positions appear to be relatively stable. In particular, the exports of dark matter of the US appear to be fairly steady and large enough to keep the US net asset position stable, casting doubts on the need for a major adjustment of the dollar or a large rebalancing of the global economy.
\end{abstract}

Keywords: global imbalances, United States current account deficit, valuation problems, Foreign Direct Investment (FDI)

JEL codes: F32, F34, F36, F41 


\title{
Global imbalances or bad accounting? The missing dark matter in the wealth of nations ${ }^{1}$
}

\author{
Ricardo Hausmann \\ Kennedy School of Government and Center for International Development, Harvard University \\ Federico Sturzenegger \\ Kennedy School of Government, Harvard University and Universidad Torcuato Di Tella
}

\begin{abstract}
This paper argues that current account statistics may provide a poor indication for the real evolution of a country's net foreign assets. This may be due to a series of factors including the mismeasurement of FDI, unreported trade of insurance or liquidity services and debt relief. Because of these problems we suggest estimating net foreign assets by capitalizing the net investment income and then estimating the current account from the changes in this stock of foreign assets. We call dark matter the difference between our measure of net foreign assets and that portrayed by official statistics. We find dark matter to be important for many countries and that it relates to FDI flows, domestic volatility, and debt relief. We also find that, once dark matter is taken into account, global net asset positions appear to be relatively stable. In particular, the exports of dark matter of the US appear to be fairly steady and large enough to keep the US net asset position stable, casting doubts on the need for a major adjustment of the dollar or a large rebalancing of the global economy.
\end{abstract}

First version: December 2005

This version: September 2006

JEL: F32,F34, F36, F41.

\footnotetext{
${ }^{1}$ Prepared for the $44^{\text {th }}$ Panel Meeting of Economic Policy in Helsinki. We thank two anonymous referees, Robert Barro, Joe Beaulieu, Giuseppe Bertola, Eduardo Borensztein, Willem Buiter, Richard Cooper, Joshua Coval, Alex Culiuc, Barry Eichengreen, Jeffrey Frankel, Sebastian Galiani, Matthew Higgins, Robert Lawrence, Gian Maria Milesi Ferretti, Ugo Panizza, Roberto Rigobon, Dani Rodrik, Andrei Shleifer, Alan Taylor, Beatrice Weder, and seminar participants at the Lunch on International Economic Policy and Faculty Seminars at the Kennedy School of Government, Harvard University, and Harvard Business School, as well as seminars at American University in Paris, Chatham House in London and New York, JP Morgan, Fedesarrollo, FIEL, Central Bank of Argentina, and Universidad Torcuato Di Tella for useful comments. The first draft of this paper gave rise to an inordinate amount of reaction. At this point at least six pieces have discussed specifically the Dark Matter hypothesis. These include McKelvey ed (2005), Buiter (2006), Eichengreen (2006), Higgins et al (2006), Meissner and Taylor (2006) and Milesi Ferretti (2006). In addition the dark matter hypothesis has caught the attention of the press. Following an op-ed in the Financial Times and a short paper on the US current account, Hausmann and Sturzenegger (2005a, 2005b), dark matter has been discussed in Roubini and Setser's RGE Monitor, see for example, Setser On the origins of Dark Matter, January 2006, the Economist America's Dark Materials, Jan 19 2006, The Wall Street Journal, Mark Gongloff, Is Dark Matter in the Deficit?, February 2006, Business Week, Michael Mandel, Why the Us Economy is Stronger than you think, May 2006, The Wall Street Journal Editorial Trade Deficit Disorder, March 2006, and The New York Times, P. Krugman, Trade Deficit, April 2006. This intellectual debate has given us fruitful ideas for preparing a revision for this paper. We thank Federico Dorso, Maria Fernandez Vidal, and Victoria Vanasco for able research assistance.
} 


\section{Motivation}

Over the last couple of years the burgeoning of the US current account deficit, reaching 792 billion dollars in 2005 alone, has led to significant concerns about the future of the US and the possibility of a major global crisis. With a brief respite in 1991, it comes after 24 years of unbroken deficits which have totaled over 5.2 trillion dollars. Once the massive financing required to keep on paying for such a widening gap dries up, perhaps because foreigners become satiated of owning such a large and rapidly growing amount of American debt, there will be an ugly adjustment in the world economy. The dollar will collapse, triggering a stampede away from American debt, interest rates will shoot up and a sharp global recession will ensue. Martin Wolf (2004) calls this situation an "unsustainable black bole" and points that "The U.S. is now on the comfortable path to ruin". Maurice Obstfeld and Kenneth Rogoff (2005) remark that "any sober policymaker or financial market analyst ought to regard the US current account deficit as a sword of Damocles hanging over the global economy". Even more dramatically, Nouriel Roubini and Brad Setser (2005) claim that "The current account deficit will continue to grow on the back of higher and higher payments on U.S. foreign debt even if the trade deficit stabilizes. That is why sustained trade deficits will set off the kind of explosive debt dynamics that lead to financial crises".

The recent and growing global imbalances, including, prominently, that of the US, has attracted substantial interest from both policy and academic circles. In a series of papers Obstfeld and Rogoff $(2000,2005 a$ and 2005b) use two and three country endowment to estimate by how much the dollar needs to fall to eliminate the US current account deficit. The conclude on a needed depreciation of the dollar of 12 to $14 \%$ in their 2000 piece, of between 20 and $40 \%$ in their $2005 \mathrm{a}$ piece, and of about 33\% in their 2005b Brookings Paper. Blanchard, Giavazzi and Sa (2005) use a portfolio model to obtain a required depreciation of $65 \%$. Somewhat less dramatically, Gourinchas and Rey (2006) find a required depreciation of between $18 \%$ and $13 \%$ depending on the assumed elasticity of net exports, for convergence to a steady state where net foreign assets become stable.

The increasing unbalanced position of the US (and the world) entails several puzzles. First, there is the puzzle of why such a large and increasing indebtedness has not led to any visible crisis, and why the world is willing to lend continuously to the US and to do so at surprisingly low interest rates. Or put otherwise, why is the US itself willing to run such large current account imbalances? While some of the recent discussion, particularly in the press, have chosen to depict the US economy as out of control, with particular attention placed on the low personal savings rate of the typical US consumer, this explanation finds itself at odds with our belief that agents are rational and maximize utility in a way that is consistent with their intertemporal budget constraints. Of course we have no lack of models in which current account crises do occur, but many of the assumptions used in those models, such as currency mismatches combined with sudden stops, while relatively well suited to emerging economies, are implausible when applied to the US. Another popular explanation for the persistence of the imbalances is that it is official sources, more specifically the purchase of treasury bills by East Asian economies, particularly China, that are keeping demand for US securities artificially large. But while the fact may be true it also provides an unsatisfactory answer: why would these governments buy into inevitable capital losses?

A second puzzle arises from the fact that if the US is a large net debtor, then someone else must be a large net creditor. According to official statistics this large creditor is not Europe (in fact Europe is a debtor as well), but Japan and the rest of the world. This implies that, over the last decade, the less 
developed countries in the world have been financing the consumption excesses of the richest countries. This adds a huge puzzle of why capital is flowing away from the less developed world, not just why it does not flow in. ${ }^{2}$

The conceptual and practical problems of this description are so large that we explore in this paper if there is something seriously wrong about this worldview. To motivate our analysis let us start by reviewing some facts. The Bureau of Economic Analysis (BEA) indicates that back in 1982 the US had about 329 billion dollars of net foreign assets (that is the difference between the foreign assets owned abroad and the local assets owned by foreigners). These assets rendered a net return of about 35 billion dollars. Between 1982 and 2005, the US accumulated a current account deficit of 5.27 trillion dollars. We should expect then that the net foreign assets of the US would fall by that amount, to say, minus 4.94 trillion. If it paid 5 percent on that debt, the net return on its financial position should have moved from a surplus of 35 billion in 1982 to minus 247 billion dollars a year in 2005. After all, debtors need to service their debt. But the number for 2005 is still a positive 17.6 billion! This means that the US has spent 5.27 trillion dollars more than it has earned (which is what the cumulative current account deficit implies) almost for free. Figure 1, which shows the net investment income of the US and the cumulative current account, makes the point that this inconsistency between the flow and stock data has been growing steadily over the last twenty years.

To respond to the incongruence of the flow and the asset data two answers have been suggested. One notes that the US has benefited from what the BEA estimates to be about 2.25 trillion dollars of net capital gains so that instead of owing 4.94 trillion, it owes "only" 2.69 trillion. These capital gains can be sizable. For example, during the 2000 - 2005 period, the net foreign asset position of the US deteriorated by 1.3 trillion in spite of current account deficits that totaled 3.26 trillion, the difference being made up by capital gains of about 2 trillion dollars. However, in spite of muting the size of deficits for recent years, the capital gains story cuts the puzzle, at best, in half, leaving a whole other half to be explained ${ }^{3}$.

The second answer to the incongruence between flow and stock data stresses the fact that the US earns a higher return on its holdings of foreign assets than it pays to foreigners on its liabilities a point made early on by Lawrence (1990) and more recently by Obstfeld and Rogoff (2005b) among many others. Figure 2 shows that this differential has been fairly persistent over the years. A careful description can be found in Gourinchas and Rey (2006) ${ }^{4}$ who document this differential return by estimating how the gross returns have evolved since 1952. They find that the US return privilege is mostly concentrated in short term liquid assets. Using their estimates corresponding to the more recent period since the end of Bretton Woods, they conclude that the tipping point for the US economy, i.e. the moment it will start paying on its net asset position, will be reached when liabilities are 1.43 times assets, thus placing the US still a long way from being a "real debtor".

Both explanations require further analysis. First if it is true that there have been significant capital gains on US foreign assets we need to understand where those large capital gains come from,

\footnotetext{
2 This issue has recently been discussed in a series of papers by Jeanne and Gourinchas (2005, 2006) as well as in Ju and Wei (2006).

${ }^{3}$ Notice that to the extent that the current account is intended to measure the deterioration in the asset position of a country, we could use the stock of net foreign assets to infer an alternative "inclusive of capital gains" current account. Interpreted this way, official statistics would already indicate that the US has run a deficit of only 1.3 trillion, not of 3.26 trillion in recent years, a point that has been surprisingly ignored.

4 See also Higgins et al (2005).
} 
particularly when it is unlikely that they come from exchange rate movements, to the extent that the dollar has gone up and down since the 1980s without any clear trend ${ }^{5}$. What are the channels by which capital gains take place? On the other hand the fact that US assets abroad deliver higher rates begs the question of whether US investors abroad are smarter than foreign investors in the US. But, aren't global portfolio investors not free to buy any assets they want? Why would foreigners consistently pick worse assets than American investors? Can't they just ask American financial institutions to manage the money for them? Alternatively, is this an equilibrium phenomenon? But if so, what does it respond to? And, is it persistent in a way that we should consider it will continue into the future?

Cline (2005) provides an excellent analysis of these questions that is a starting point for what we do in this paper. While Cline shares with the consensus a concern for the evolution of US net foreign asset position moving forward, he provides several arguments that suggest why these concerns may be overstated. He introduces the concept of capitalized net capital income (the present value of net income), which we will use extensively below, to show that "the United States has remained a persistent "economic" net creditor throughout the last three decades", and applies standard sustainability analysis to study the future evolution of the US current account, only to find that sustainability is fairly robust. He acknowledges this is the result of the difference between the return on US assets abroad and the return of foreigner's assets in the US, and while he relates this to the risk characteristics of the assets he still concludes this differential to be "basically a puzzle".

Our paper argues that the inconsistency between flow and stock data can be explained by two complementary phenomena. One, that net foreign assets may not be properly measured, most noticeably foreign direct investment (FDI), which is computed on the basis of a very strict set of accounting rules that sometimes may not capture the true earning potential of the underlying assets ${ }^{6}$. The second idea, builds on the existence of a return differential. We argue, uncontroversially, that this differential is an equilibrium phenomenon due to the fact that foreigners choose to hold the assets of some countries (the US or Switzerland, for example) in spite of their lower return because they perceive these assets to be endowed with other virtues (e.g. safety) which make them attractive in spite of their lower yield. More controversially we suggest that this differential can be assimilated to an asset (that values the underlying attributes that explain why this differential exists), so that the capitalized value of this differential should be added to the measured stock of net foreign assets.

We group both the unmeasured assets, as well as the capitalized value of the return differential responding to unobserved attributes into a concept called dark matter. In the next section we suggest how to compute the stock of dark matter. Once dark matter is estimated we can obtain a measure for the net stock of foreign assets. The change of these over time will be our estimate of the current account. We will see that our current account aligns itself very well with the official data for most countries, though some cases present differences with reported statistics. In Section III we discuss the economic reasons that explain the existence of dark matter and test their relevance for a cross section of countries. We find that dark matter relates in a fairly systematic way to FDI flows, risk characteristics of local output and debt relief. In Section IV we address the issue of global imbalances. How do global imbalances look once dark matter has been taken into account? We find that our new description points to a world were net asset positions seem to be fairly constant. In

\footnotetext{
${ }^{5}$ On this see Cline (2005) and Gros (2006a).

${ }^{6}$ Gros (2006) agrees with us that this item is subject to gross mismeasurement, but argues that the bias goes in the opposite direction to what we suggest below.
} 
particular, we show that once dark matter is taken into account the US economy has not been running current account deficits during the last two decades. Section V concludes with some closing thoughts and suggestions for future research.

\section{Section II. Measuring Dark matter}

The interest in a concept such as the current account is that it is related to the change in the net asset position of a country. This explains why people worry about large negative external positions. In fact, this is the rationale that we followed to look at the US numbers in the introduction of this paper, only to find out that it led to a large inconsistency. The problem comes from the fact that given the standard accounting rules capital gains and return differentials can be substantial and persistent making the relationship between the current account and the change in net foreign assets quite weak.

Thus we propose an alternative way of measuring the current account, in a way that rescues the relationship between our definition of the current account and the change in net foreign assets by defining the first as the change in the latter. In particular we will measure the stock of net foreign assets (NFA) as the capitalized value of the net investment income (NII), discounted at a constant rate of interest $(r)^{7}$ :

$$
N F A_{t}^{D M}=\frac{N I I_{t}}{r}
$$

The superscript $D M$ corresponds to dark matter, a term that we have chosen to reflect the discrepancy between our measure of net foreign assets and the measure that can be obtained from official figures or from accumulating the current account imbalances. The name is taken from a term used in physics to account for the fact that the world is more stable than you would think if it were held together only by the gravity emanating from visible matter. In the same way that physicists infer matter in the world from its gravitational pull (but not from adding up the visible matter) we infer the assets from their returns and not from adding the current account imbalances. As a result countries with net investment income larger than what is presumed on the basis of their asset base will have dark matter assets, while countries for which the net investment income is too low will have dark matter liabilities.

In turn, we define the current account as the change in net foreign assets so defined:

$$
C A_{t}=N F A_{t}^{D M}-N F A_{t-1}^{D M}=\frac{N I I_{t}-N I I_{t-1}}{r}
$$

\footnotetext{
7 The use of a constant interest rate has two immediate advantages. First, in the global economy each financial claim appears twice: as an asset in one country and a liability in another. We should value that claim equally in both countries. Hence, it is important that we use the same interest rate in both countries. Second, we choose a constant rate so that changes in our measure of assets depend only on changes in the income flow of the assets and not on variations in the price-earnings ratios. This allows a cleaner visualization of the evolution of flows. In fact, the level of the interest rate we choose is irrelevant for our story and similar results would obtain if we used an interest rate computed from market rates.
} 
This way of computing the current account has been suggested by Cline (2005) and previously by Ulan and Dewald (1989). It was discussed by US government officials, but the Bureau of Economic Analysis eventually discarded it on the difficulties associated with choosing a discount rate (see Landefeld and Lawson, 1991).

Choosing to value the assets on the basis of their returns is just like valuing a company by calculating its earnings and multiplying by some price-earnings ratio, or valuing a property based on its rental value. As we know from the corporate finance literature for an individual company, the earnings of any given year may give an unreliable measure of its true earning potential, but if we average over an economy and look at trends over a couple of years this simple methodology delivers reasonable results. Of course, this opens many methodological questions, for example what exactly this price earning ratio should be and why the discount rate should be the same, even for assets with very large differences in risk characteristics.

More precisely we can understand the sources of the stock of dark matter (DM) by noticing that

$$
D M=N F A_{t}^{D M}-N F A_{t}=\frac{N I I_{t}}{r}-N F A_{t}=\frac{\tilde{r}\left(N F A_{t}+\mu_{t}\right)}{r}-N F A_{t}=\frac{\tilde{r}}{r} \mu_{t}+\frac{(\tilde{r}-r)}{r} N F A_{t},
$$

where $N F A_{t}$ stands for the official measure of net foreign assets. In this expression we allow for assets to be mismeasured, with $\mu$ indicating the error in measurement. In addition we assume assets to yield a rate of return $\tilde{r}$ different from the constant rate used for discounting. The two terms in the last expression of equation (3) show that dark matter may have two origins: the capitalized return to unaccounted assets and to return "privileges". These privileges may arise because assets abroad earn a higher rate of return or because liabilities pay a lower rate. ${ }^{8}$

We will differ our discussion of measurement errors in the asset stock until the next section, but from the second terms of equation (3) it should be clear by now that our difference with Gourinchas and Rey (2006) is that we capitalize the return differential, add it to the stock of net foreign assets and then adjust the current account accordingly. It is the fact that we consider as an asset the capitalized value of the return differential what makes our description of the current account dynamics so different from the standard description.

Why would we want to do so and what is the rationale for using a fixed rate of interest? There are three main reasons why assets in equilibrium may yield different returns: surprises, risk premia and embedded services. Surprises refer to the fact that assets may turn out to have a lower rate of return

\footnotetext{
${ }^{8}$ The second term in equation (3) is important in that it may change, sometimes dramatically, rendering the stock of dark matter quite volatile. McKelvey et al (2005) refer to the very large volatility of dark matter, something that he found did not bear well with what they believed were stable underlying economic reasons for the existence of dark matter. Equation (3) clarifies the point by showing that dark matter will be affected by the capitalized value of changes in the actual return differentials. Thus small changes can lead to very large swings in our dark matter estimate. As much as in corporate finance, earnings in a particular year, may provide a poor guide to the income of a particular corporation over the medium term. In our case the income flow is the average of many different individual returns, but it is still true that these returns may be affected by macro shocks, thus still exhibiting some volatility. Under this light, our estimates for any particular year should be taken with care, with averages over longer periods being more informative. Trends over twenty five years, as what we use in this paper, are relatively stable.
} 
if faced with expropriation, restructuring or unexpected negative business conditions, risks that require an ex ante higher discount rate to compensate for these expected losses. In our computation, surprises are already taken into account because we work with ex-post data. Averaging out over a large number of assets and over long period of time it seems implausible (though not impossible) that realized returns may differ significantly from expected returns. Buiter (2006) has argued that over short periods this may lead to distortions due to a peso problem. Without providing a formal test we believe this is unlikely to be a problem in our case considering that our data spans a period of close to twenty five years which have seen several episodes of financial crises?

The second reason for a differential rate of return is a risk premia, which implies that ex-post the two assets may have a persistent difference in returns. For example, equities have traditionally earned a premia over bonds that compensate for their higher risk. This differential over the very long period from 1890 through 1979 has been, on average, of 6\% per year. ${ }^{10}$ If we discount the earnings of stocks by the same rate as for bonds, their value would largely exceed market valuation. We can interpret the difference between this higher valuation and the market value as the price paid by the market for the insurance sold by whoever chooses to hold equities. In this view, the risk premia is assimilated to the sale of a service, which in this specific case assimilates to insurance services.

We believe that for the purpose of studying global imbalances it makes sense to call these differences in returns an asset, because they correspond to services that are sold and, on average, paid for. In fact, while this may sound controversial it is exactly what is done in standard GDP estimation. In other words, many components of GDP are imputed by assimilating return differentials to the sale of specific services, exactly the same way we do in this paper. For example, a sector where net interest differentials are imputed as income is the banking sector. ${ }^{11}$ In the case of the US, the System of National Accounts (SNA) recommended

"measuring implicit financial services to depositors, using the difference between a risk-free reference rate and the average interest rate paid to depositors, and it recommends measuring the implicit services to borrowers using the difference between the average interest rate paid by borrowers and the reference rate" (Fixler et al, 2003, p. 33)

Fixler et al (2003, p 34) explains the logic

"depositors could dispense with the services of a bank entirely and keep their money in securities paying the reference rate of interest. Depositors who forego the opportunity to earn the reference rate in order to obtain the services of a bank. choose to pay the implicit price for depositor services equal to the margin between the reference rate and the deposit rate"

So, while in US national accounts, the return differential is used to value financial services, we extend the same methodology to return differential in assets to value insurance services. Thus, when foreigners decide to invest in the US or Switzerland at a lower rate, it is because they value the insurance services provided by this investment. In this case we would say the US and Switzerland are

\footnotetext{
${ }^{9}$ However one piece of evidence provides some support to the idea that some countries may have enjoyed extremely high ex post returns over the last five years that are probably unsustainable. Klingen, Weder and Zettelmeyer (2005) show that the return on emerging markets during the 90s, have been on average unusually high from a historical perspective, a feature that they attribute to very large negative returns in the $1980 \mathrm{~s}$.

${ }^{10}$ See Mankiw and Zeldes (1991).

11 We thank Joe Beaulieu for pointing this out to us.
} 
selling insurance abroad, in the same way banks sell financial services by paying a lower rate on their deposits.

Why is this interpretation useful? First, because there has been a growing awareness that intangible capital is an important source of income. In a much celebrated paper Corrado, Hulten and Sichel (2006) argue that US national income accounts miss about 800 billion a year in intangible capital, and thus underreport the total capital stock of the economy in close to 3 trillion dollar. Parente and Prescott (2002) had already argued in the same line, providing some back of the envelope estimates of intangible investment that were even larger than that of Corrado and co-authors. The point is that, to the extent that this capital is there, it will generate income on a steady basis, implying that the income provides a better way of assessing the true potential of such capital stock in a way that official statistics will not be able to. Second, because the return differential arising from risk premia, liquidity or safety perceptions correspond to embedded services that provide a return, which should be taken into consideration when understanding global positions.

By capitalizing the income we are redefining the stock of assets in a way that more explicitly shows the value of the underlying services, thus providing a better measure of the vulnerabilities build in each economy. In other words, capitalizing this steady return differential includes in the asset estimates the advantage or disadvantage of local assets reflected in the differences in the rates of return, providing a more coherent picture of actual global imbalances. For this reason, we believe the points made to us (Buiter, 2006, Milesi Ferretti, 2006, Eichengreen, 2006) that our approach may lead to an overestimation of US's foreign assets to the extent that it discounts the flows obtained from riskier investments abroad at the same risk free rate that the US charges on its liabilities, is misguided. To the extent that we work with ex-post returns that reflect expected returns and which show a return premium that is consistently paid (as is any insurance premium) the value of this differential should be included in the analysis of the net asset position. For example Figure 2 shows that in the case of the US this differential has been pretty steady over the last 30 years. ${ }^{12}$ Kugler and Weder $(2004,2005)$ make a similar point for Switzerland.

Our measure does appear to hinge on a blind trust in the net income data, at least in comparison with official stock data. But how good is either of these data? The truth is that we do not know. However we don't feel we should be called to make a judgment on this. Our analysis simply points out to a discrepancy between the two data sources which needs to be addressed and understood. Gros (2006a), for example, agrees with us that the stock data is wrong by pointing out that, for example, in the US, surveys systematically miss on assets that foreigners hold in the US, a fact that, if true, increases the inconsistency between the two series.

Gros (2006b) tries to explain the puzzle by arguing that the income flow data is wrong as well, because foreign firms in the US seem to understate retained earnings. Some evidence is provided by the fact that once investments are categorized as direct investment reported retained earnings fall dramatically. Gros disregards transfer pricing as an explanation (so does Mataloni, 2000), but still assuming foreign firms can actually dodge the US taxman, the question remains as to how these distributed earnings are used. If foreigners purchase other assets in the US then they would be registered as an increase in other foreign assets in the US, very much as retained earnings by US firms abroad are computed as an increase in FDI abroad. Gros argues that retained earning in the

${ }^{12}$ This graph is computed with FDI at current cost in order to span a larger number of years. 
US should be similar to those of US firms abroad, so that they could be pulled out altogether from BOP statistics. We think there is no ground for this assumption, but if one is willing to make it, it would imply a 100 billion overestimation of the net income which in our methodology (when a 5\% discount rate is used) would be equivalent to a 2 trillion drop in net foreign assets. Because Gros (2006a) suggests that net foreign assets stocks are 1 trillion less than actually measured, in the Gros accounting system there is still a large inconsistency between official stock data and the income flow data for the US except that it is just 1 trillion smaller than our estimate, making it still sizable. ${ }^{13}$

Another issue that has been raised several times (see for example Setser 2006, Eichengeen 2006 and Lawrence and Lara, 2006) is the issue that the divergence between the flow data and the stock data, may stem from tax avoiding strategies. Lawrence and Lara (2006), in the context of studying the Puerto Rico economy, argue that this advantage is highest for firms with large intangible assets, which explains why there is a disproportionate amount of $\mathrm{R} \& \mathrm{D}$ intensive industries such as pharmaceuticals, instruments and electronics located in the island. These firms allegedly "allocate high-cost activities, such as R\&D spending, to the parent company and highly profitable production activities (that benefit from the R\&D) to the foreign (or Puerto Rican) subsidiary."

But does the tax shifting hypothesis stand up the test of the data? The BEA reports an income in 2005 of 227 billion dollars from foreign direct investments abroad. Most of this comes from Europe, Canada and Japan (that add up to 139 of the total), where it is unlikely that tax considerations are that relevant. Among "well known" low tax jurisdictions, Ireland stands out with 12 billion, Bermuda with 8 billion and UK Caribbean with 7.7 billion. What role can these play in explaining the story? In fact, for the tax issue to explain the mismatch between asset and flow data on a sustained basis requires that profit shifting be increasing fast. If it is true that the US runs a current account deficit of 600 billion in a particular year, this implies that there should be roughly 30 billion more in net payments the following year (using our arbitrary 5\%). So for this not to show up in the net income from investments it requires that tax shifting increase relative to previous years by the same amount. If this reasoning is correct the numbers don't stand up to scrutiny. In 2000 the BEA reports income from Bermuda for 6.4 billion, from Ireland of 5.7 and 1.6 billion from the UK Caribbean, so the change is quantitatively small relative to what is necessary for tax shifting to be an important part of the story. Mataloni (2000) also checks if reported profitability is sensible to firms with large intrafirm imports, but finds no relationship.

Before discussing the sources of dark matter let us discuss the estimates obtained of applying the simple rules in equations (1)-(3) using an arbitrary 5\% rate, which implies a price-earnings ratio of $20 .{ }^{14}$ Figure 3 a shows a scatter plot that illustrates how the two measures, the current account as measured from changes in the net stock of foreign assets computed from capitalizing the net investment income and the official current account track each other for the 94 countries with

\footnotetext{
13 A point that has been made (Buiter, 2006) and which we think is not valid is that mistakes may creep because income data is computed on an accrual basis. Thus if a country is in default, for example, the interest accrued but not paid will still be imputed to the income flow. While this may lead to some distortions, these apply to a very small set of countries, and only until the default is resolved. Once defaults have been cleared, while the numbers are not revised backwards, our final estimation for the stock of assets, and therefore our cumulative current account numbers would still be correct. There is one case in which this criticism is still valid, in that our data goes through 2004 when the Argentina default had still not been corrected. However, foreigners held a relatively small fraction of this debt, so that we expect this not to affect significantly the numbers.

14 In this exercise and what follows we use net foreign investment income receipts, i.e. netting out net employee compensation which is not a form of capital income.
} 
complete data from 1980 through 2003. Countries along the forty five degree line are countries where our estimates of the current account match official statistics. Countries to the right of the forty five degree line have dark matter assets (have exported dark matter), as their imputed net asset stocks appears larger than indicated by the official current account. Countries to the left of the 45 degree line have dark matter liabilities (imported dark matter assets). While most countries lie close to the forty five degree line (as an example the two estimates for Australia are 357 and 352 billion), the data shows some important outliers: the US, UK and Switzerland as exporters of dark matter, and Ireland, Italy and Germany appear as importers. Figure $3 \mathrm{~b}$ zooms into the central cluster to show that the relationship between the two measures is in general fairly positive. Table 1 provides some plain vanilla regressions to suggest that the correlation is strong. In fact, once the US and the UK are withdrawn from the sample the coefficient relating both measures is exactly 1.00 and highly significant, though this result, as shown in the last column, is mostly driven by Japan. As anticipated in our discussion in the introduction, the US shows virtually no change in its net foreign assets which in our accounting implies no cumulative current accounts during this period. This implies, in a nutshell, that it has been exporting dark matter so that its net investment income has remained relatively stable. While the US is a large outlier in this figure, its prominent role in international financial markets makes understanding the vulnerabilities faced by this economy particularly important.

Meissner and Taylor (2006) provide an alternative computation of dark matter for G-7 countries by estimating by how much returns on their net foreign assets differ from a world average. Their results, obtained for the same data period as for our figure 3, provide somewhat similar results. They find that US, UK and Japan are statistically significant exporters of dark matter (i.e. have yield returns above world average). In Figure 3, US and UK appear as exports of dark matter but not Japan. They find that Canada and Italy are importers of dark matter, something that is consistent with Figure 3, but that France and Germany are exporters of dark matter (though not in a statistically significant fashion). We find both countries to be importers of dark matter. For the US, Meissner and Taylor find a return differential of about .5\% of GDP, which for 2005 data for the US would imply a stock of dark matter of about 1.25 trillion. However, as of recent, they show the differential for the US to be closer to $1 \%$, yielding a dark matter estimate of about 2.5 trillion.

\section{Section III. Sources of dark matter}

We believe that there are at least three main factors that account for the accumulation or decumulation of dark matter and they all involve a persistent return differential between assets and liabilities. The difference in returns may originate in three main sources: a return differential for FDI investments, the sale of insurance, and the provision of liquidity services.

The first channel involves the notion that FDI investments abroad are a vehicle for the dissemination of ideas, blueprints, knowledge and that they are the vehicle for unaccounted exports of services produced by headquarters and used by affiliates around the world. FDI investors purchase assets in order to invest, but also bring with them a blueprint, a product and a business know-how that is usually poorly accounted for. Because of the difficulties in tracking the trade of these services across national borders, it is likely that numbers underestimate either the net worth of the companies or the exports of the source countries. In fact, countries that are long FDI are probably exporters of services through this channel. The second channel may arise because the underlying stability or instability of a given economy allows some economies to sell some of their 
stability to the rest of world, and others to diversify away some of their own instability. Either case is akin to the trading of insurance services and will show in a return differential between local and foreign assets. The third channel is related to the provision of liquidity services, basically through the use of a foreign currency or paying a premium for purchasing instruments in liquid financial markets.

Can these channels be quantified? Which one is more relevant? In what follows we discuss each in turn, providing some partial evidence, while at the end of the section we provide a more systematic test based on evidence obtained from data for a cross-section and panel of a large sample of countries. ${ }^{15}$

\section{Foreign Direct Investment}

There are three basic methodologies for estimating FDI assets. The most traditional is the use of book value estimates, which, while commonly used, provides a fairly poor measure of the value of investments abroad. The US Department of Commerce (1990) cautions itself that "The international investment position should be interpreted with caution because it is only a rough indicator, not a precise measure. On the one hand, US assets abroad probably are understated because direct investment is carried at book values..." (p. 21).

Book value can be improved upon by using the current cost method estimation, which adjusts book value by estimated changes in the value of the underlying investments, usually exchange rate and inflation adjustments. A third alternative is to adjust the values using stock market data, thus approximating market valuations for the underlying assets. As described in Lane and Milesi Ferretti (2006) in recent years a wider range of countries have implemented market valuation methodologies, but book value remains the method of choice for a large number of countries. ${ }^{16}$ To obtain the market value, current methodologies start from the book value declared by companies and try to approximate their market value by multiplying book values by the market to book ratios in host countries. This makes sense to the extent that host markets capture the profitability, tax, expropriation risks, and similar types of constraints faced by firms in those markets. However, it is also equally reasonable to think that the productive capacity of a transnational may also be somewhat captured by the source country stock market. An example may help illustrate the point. We believe that the S\&P 500 may better capture the profitability of Intel-Costa Rica, than the San Jose stock market. In fact, we believe the San Jose stock market probably has no relation to the profitability of Intel's factory in Costa Rica. The company is not listed there, whereas its profits are considered by investors in the US when valuing Intel. If instead of using the host country stock market we use the S\&P 500 market to book ratio to adjust FDI book values, US FDI would experience an increase in "measured" value by the equivalent of 2.74 trillion, actually sufficient to make the US a net creditor. ${ }^{17}$ This results from the fact that the market to book ratio of the S\&P 500 was 2.99 which applied to the BEA estimate of book value FDI of 2 trillion (which may be

\footnotetext{
${ }^{15}$ See also Cooper (2005) who mentions most of these channels.

${ }^{16}$ For the specific case of the US it has been long since the BEA introduced a market value alternative to the original measure, and updated the book value alternative by its improved current cost method. For a careful (and official) description of the two methodologies see Kozlow (2002). The original book value is no longer published though still being reported in the BEA's website.

${ }^{17}$ This computation is done with 2004 data the latest available at the time of writing.
} 
contrasted to the estimates of FDI of 2.4 trillion at current cost and 3.3 trillion at market value) gives an estimate of six trillion, 2.7 trillion above the market valuation suggested by BEA. ${ }^{18} 19$

Figure 4, explores this issue in more detail for the US by tracking three measures of US net foreign assets: BEA's official estimation, the net foreign assets according to our dark matter capitalization methodology, and an alternative version of BEA's net foreign assets obtained by adjusting only the valuation of US FDI abroad by using the market to book ratio of the S\&P500. The numbers show that both BEA's net foreign assets and the series including the adjustment for FDI behaved very similarly through the early 1990s but diverge afterwards. Towards the end of the period, the adjusted series delivered a number similar to our methodology showing a virtual balance in the US net foreign asset position. ${ }^{20}$

How can the presence of dark matter in FDI be tested? One alternative is to look at yield differentials. On this, the evidence provides mixed results. Again focusing on the US, Higgins et al (2005) provide supporting evidence in favor of large differential returns in FDI. They split US net foreign assets in three categories: FDI, interest rate sensitive assets and equities, and find that US benefits from a return differential, but only on the FDI class, and that this difference remains basically unexplained (see Kitchen, 2006). In contrast, Gourinchas and Rey (2006) compute a more comprehensive gross returns figure (i.e. including capital gains) and when comparing foreign assets in the US with US assets abroad find that there are large differences in the returns of debt, equity, bank loans and trade credit in favor of the US, but virtually no difference in FDI.

Fortunately we can bring the evidence of other countries to bear on this issue. If FDI is a way to exploit a business idea abroad, countries that are long FDI, are countries that in general will be net exporters of ideas, the value of which will be embedded in the income flow of their subsidiaries. To the extent that the true value of these ideas is not fully captured by official statistics, they would show "larger than normal" income flows. The reason this underestimation may occur is very simple. Much of the productive capacity of subsidiaries abroad depends on the productivity and services provided by headquarters. However, many of these services are not computed as exports from headquarters to their subsidiaries (accounting rules better capture the transfer of goods, but the transfer of services has to be grossly unaccounted). Had these flows been reported they would have led to more exports and a stronger net asset positions for the source country reconciling the stock data with the income data. Our approach is a way of getting around those missing exports and approximating their value as inferred from the income stream they generate. Similarly, countries that are recipients of FDI will show net investment payments large relative to measured assets. We return to this issue below in the context of a cross country testing for the sources of dark matter.

\section{Insurance}

Another possible reason why dark matter may exist is because countries, when trading assets, implicitly buy and sell insurance services. According to this interpretation countries that are more

\footnotetext{
18 We thank Willem Buiter for suggesting this computation to us.

${ }^{19}$ Higgins et al (2006) provide an alternative to this estimate by adjusting US asset stocks by a price earning ratio. In doing so they increase the value of US assets by 400 billion and decrease the value of liabilities by 600 billion, rendering a change in asset positions of 1 trillion dollars.

${ }^{20}$ If a similar analysis is done on the foreign assets in the US, this would diminish the value of foreigner's holding in the US, increasing the net position of the US.
} 
stable will profit from a return differential and countries that are more unstable, will need to pay for such insurance by borrowing at higher rate or investing abroad at a lower rate. To the extent that the underlying risk properties of the economies remain relatively stable, then so will the return differential, which, in turn, will be a source of income. For example, Kugler and Weder (2004 and 2005) study these return differentials for Switzerland, a natural provider of insurance services, particularly after WWI. They find that the return differential originated in Switzerland's neutrality during that war, and has remained very strong and persistent since.

These return differentials seem to be quite predictable. Klingen, Weder and Zettlemeyer (2005) find that emerging market debt has ex-post delivered a rate of return of about $1 \%$ above equivalent US securities, and that this return has been relatively stable over long historical periods. This result is consistent with the findings in Gourinchas and Rey (2006) for the specific case of the US: a 1.56\% return differential that is especially significant for short term liquid assets for the period 1952-2004. They find this return effect to increase to 1.89\% during the period 1973-2004.

Barro (2005) explains this through a model where the equity premium puzzle is influenced by the possibility of unusual but large negative shocks, with the equilibrium return on bonds falling substantially when these large unusual events become more likely. His model could be used to explain why the value of insurance provided by the US has increased starting in mid 1990s in response to the series of international financial crises that followed the Mexican crisis of 1995. The common buzz word "flight to quality" somehow captures this effect and explains the significantly lower interest rates paid by the US during this period. In fact, in the Barro framework it could be argued that this benefit may have further increased after $9 / 11$ as the US is, even when the most likely victim of a potential terrorist threat, still the economy that can better deal with the global implications of such threat.

\section{BOX Charging an Insurance Premia in an Arrow-Debreu World}

In order to visualize how some countries may charge a risk premia consider a one period two country multiple-states world endowed with a complete set of Arrow-Debreu contingent securities. Each $S$ state of nature $(s)$ has probability $\pi(s)$, and each $S$-contingent good carries a price $p(S)$ Equilibrium requires supply and demand in the $S$ contingent states to balance, i.e.

$$
C(s)+C^{*}(s)=Y(s)+Y^{*}(s)
$$

where the star refers, as usual, to the foreign country, $C(s)$ refers to consumption in state $s$ and $Y(s)$ is endowment in such a state. With CRRA utility of the standard form $C^{1-\rho} /(1-\rho)$ the standard Euler equation for the maximization of expected utility implies the price relation for state contingent claims:

$$
\left(\frac{C(s)}{C\left(s^{\prime}\right)}\right)^{-\rho}=\frac{p(s) \pi\left(s^{\prime}\right)}{p\left(s^{\prime}\right) \pi(s)},
$$

and likewise for the other country. Substituting the equilibrium conditions (B.1), in (B.2), implies 


$$
\frac{p(s)}{p\left(s^{\prime}\right)}=\left(\frac{Y^{W}\left(s^{\prime}\right)}{Y^{W}(s)}\right)^{\rho} \frac{\pi(s)}{\pi\left(s^{\prime}\right)} .
$$

Notice that prices will be actuarially fair if and only if total world output is the same in all states of nature. However, when output in one state of the world is larger than in another the state that is in relative abundance will sell at a discount.

Figures B.1 and B.2 show in a two state world how the relative endowments of countries across these states may translate into a risk premia paid by the country with the more volatile endowment. In figure B.1 consider a home country that has a stable income profile (its endowment in the two states is the same, i.e. on the 45 degree line) while the rest of the world has a skewed income stream. After trading in Arrow-Debreu securities the world economy will operate at the diagonal. But to the extent that there is aggregate uncertainty equation (B.3) indicates that the price of output in the high income state is lower than that of the low income state. So for transferring income to the rest of the world in the low state the home economy obtains a compensation that is positive in expected value. This is a way to visualize the insurance premium that creates dark matter. Figure B.2 illustrates the extreme case of infinite risk aversion where the indifference curves become flat immediately away from the $45 \%$ degree line. In this case the home country appropriates virtually all the gains from providing just a tiny bit of smoothing services, the horizontal shift provides the measure of the value of the insurance services.

So the discussion of whether this differential will be stable or not, needs to focus on the fundamentals underlying the reasons why a given economy is expected to be more stable and predictable than others. To the extent that a country has permanently more stable output the insurance services income should be expected to remain, or even to grow with the ability of other countries to participate in world financial markets. The capitalized value of the flows that compensate for this insurance would appear as dark matter. ${ }^{21}$

\section{Liquidity}

Our third source of dark matter is the unaccounted value of the liquidity services provided by some countries. The simplest example is when people around the world need liquid assets and choose to hold a particular currency, dollars, pounds or euros in cash, which earns them a zero interest rate. By having foreigners accumulate this currency, and paying no interest on this, the source country can accumulate current account deficits without deteriorating its net investment income account. This so-called seignorage, or the unmeasured provision of liquidity services is a source of dark matter. But liquidity services do not originate uniquely from seignorage, deep financial markets may also carry a liquidity premia that allows the issuer to pay lower returns.

But how important is this source? The evidence does not seem to support the liquidity story. Buiter (2006) estimates exports of dark matter in seignorage of between 210 and 525 billion, a small share of the total. Longstaff (2001) finds the average liquidity premia for US treasuries to run between 10

\footnotetext{
${ }^{21}$ Shiller (1993), for example, computes the value of claims to output for different countries and finds that the volatility of these claims is lowest for the UK and the US. (see Obstfeld and Rogoff, 1996).
} 
and 16 basis points. Applied to the stock of US treasuries it delivers only very small exports of dark matter. $^{22}$

\section{Other sources of dark matter}

While the above are the most important sources of dark matter they are by no means the only ones. In order to gain some intuition as to other sources of dark matter, Figure 5 shows the cumulative exports of dark matter for all countries for the period between 1980 and 2003, both in nominal values and as a percentage of GDP and contrasts it with the equivalent cumulative official current account. A number in the upper left quadrant, for example, identifies economies that have compensated their current account imbalances with exports of dark matter. The US appears here. On the contrary countries in the lower right quadrant are countries that have imported dark matter in the face of large current account surpluses. Of course the nominal values are strongly influenced by country size, but when taken as percentage of GDP the data allows to identify economies that, while smaller, may show substantial trade in dark matter.

For example, when expressed as a percentage of GDP it is Nicaragua and not the US that appears prominently in the upper left quadrant. What is the source of dark matter exports for Nicaragua? To the extent that we are identifying reasons for a current account imbalance not to show as a deterioration in net investment income, the most likely candidate in this case is aid or debt relief. In the lower right quadrant are energy or FDI champions whose current account surpluses have to some extent been compensated by exports of dark matter.

The clear negative relation present in these graphs is shown in Table 2 to be statistically significant and large in size. Table 2 indicates that, as a percentage of GDP, a larger cumulative deficit of 1\% has led on average to exports of dark matter of about .8\% of GDP. This anticipates one of the main implications of our work: to the extent that countries that have surpluses in their current account import dark matter and countries with deficits typically export dark matter, global disequilibria must be smaller than reported in official numbers. This will be the reason why we will find below more stability in net foreign positions than that usually derived from official numbers.

While our approach has been found controversial, it fits relatively well with a larger recent literature on global imbalances that have stressed other channels by which dark matter can be created. Michael Dooley, David Folkerts-Landau and Peter Garber (2004) argue that the imbalance comes from peripheral countries adopting export led strategies with undervalued pegged exchange rates and capital controls. In this approach, dubbed Bretton Woods II, some countries are willing to purchase US assets at lower (expected) returns as part of an implicit contract with the US by which they are guaranteed access to its good market, in our words they would be "purchasing" the access to the US market, another form of trading dark matter. Ricardo Caballero, Emmanuel Farhi and Pierre-Olivier Gourinchas (2005) attribute the current imbalances to a form of financial backwardness in some fast-growing countries such as China which prevents them from writing claims on productive assets. This forces their residents to use their savings to buy foreign assets and allows foreign companies, to own the Chinese productive assets, providing an alternative explanation for the return differential. Ju and Wei (2006) provide a similar story. In this interpretation the US sells financial services and charges for it.

${ }^{22}$ The stock of marketeable treasury bills in december 2005 was of 4.14 trillion which multiplied by Longstaff's upper bound gives 6.7 billion yearly. 


\section{Testing for the sources of dark matter}

Having gone through the discussion on the sources of dark matter we now address the issue of testing which of these sources appears to be important in the data. We tackle the testing in two parts. Because our dark matter measure may have substantial volatility from year to year, our main test relies on looking at the exports of dark matter for a cross section of countries over a relatively long period. Our second test relies on an unbalanced panel including all countries with data for the last twenty five years. Because of the volatility of year to year measures we view the results from the panel as providing only complementary evidence to the initial set of results.

Table 3 shows the results for the cross section. The dependent variable is the accumulated stock of dark matter exports between 1980/2003 in terms of 2003 GDP $^{23}$. In the estimation we relate this measure of cumulative exports of dark matter to a series of variables that relate to the stories developed above. To test the mismeasurment hypothesis we include the stock of FDI assets and liabilities (we use the FDI stocks in 2003 also as a percentage of the GDP that year), an OPEC dummy, and spending in R\&D in each country also measured as a percentage of GDP. We argued that mismeasurement could be related to FDI flows, and may include the unnacounted exports of know-how. We expect these to show strongly in countries that are recipients of FDI, as they would buy into the know-how of other countries. While we expect the FDI assets to lead to exports of dark matter this result may be muted for a large sample of countries where FDI may also respond to unstable conditions in the home economy. The spending in $\mathrm{R} \& \mathrm{D}$ variable attempts to capture the role played by the ability of local firms to innovate as a source of dark matter exports. Finally, the OPEC dummy attempts to capture both the mismeasurement of firm value in response to changes in terms of trade, or the import of know how by this industry. ${ }^{24}$ To test the importance of insurance services we include a measure of the cyclical volatility of GDP obtained as the standard deviation of deviations from an HP trend. Finally, to test for other sources of dark matter we include a variable for HIPC countries which have been favored by debt relief, as well as a measure of corporate taxes to test for the possibility of tax shifting. A rule of law variable is included to test the Caballero-Wei hypothesis. The exact definitions and sources for all variables are detailed in Table A.1. We have 79 countries for which we could compile a complete set of data for the period 1980/2003 and a broader group of 109 countries for which we have incomplete or scattered data running up to 2003. We choose to run the regression for the group of countries with complete data and as a robustness check for a smaller sample of 99 that excludes the ten poorest countries from the 109 for which there is some data. These countries had very few observations, probably do not trade significantly in dark matter but introduced significant noise into the sample.

The results provide partial support for some of the channels discussed above. Because they correspond to the main hypothesis we want to test, we start in column $\mathrm{i}$ including only the fdi variables and volatility measures for the 79 countries with complete data. Column ii includes the remaining economic variables while column iii also includes the opec and hipc dummies. Columns iv-vi runs the same specifications for the larger set of 99 countries. Finally, column vii restricts the estimation to the group of industrial countries (list of countries is provided in table A.2).

\footnotetext{
${ }^{23}$ An alternative specification where we take averages over the sample of the variables as a percentage of GDP delivers very similar results.

${ }^{24}$ However the OPEC variable may also capture an insurance component, as large portfolios need to be allocated and usually are done so in safe locations.
} 
The results seem to be consistent across specifications and across sample groups. They show that countries that are short foreign direct investment tend to import dark matter. The effect seems to be large with a $1 \%$ increase in the FDI liabilities as a percentage of GDP inducing an increase of between .65 and $1.2 \%$ in dark matter exports over the 23 years, also measured in terms of GDP. The FDI assets variable is quite unstable and not significant, except when considering the subsample of industrial countries. This is expected, as among the industrial countries, the motivation for increasing FDI assets are probably associated to exports of dark matter, whereas in the case of lower income countries, FDI may also be associated to the purchase of insurance services.

The volatility measure enters with the expected negative sign. An increase in 1\% in the volatility of the cycle implies typically a loss in dark matter exports of about 10\% of GDP over the whole period. Finally HIPC countries have typically enjoyed debt relief the equivalent of exports of between $78 \%$ and $120 \%$ of GDP in dark matter and oil countries have paid anything between two thirds to one GDP over these 23 years $^{25}$. These results remain virtually unchanged for the two samples though for industrial countries the effects of the volatility variable disappears, indicating this is not an important channel for this group.

In summary the results seem to support the mismeasurement hypothesis, which appears to be particularly strong among industrial countries, while the insurance channel also appears strong, but only when including non industrial economies. On the other hand the variables on scientific innovation, rule of law and tax shifting variables do not appear significant in any of the specifications.

Table 4 shows the results from a panel both with pooled regressions and fixed effects. In these regressions we exclude the variables that do not change significantly within the sample for each country and restrict ourselves to the sample of countries for which we have the complete data set using the whole sample period 1980-2004 and we present the results for the full sample and for the more restricted samples obtained by excluding OPEC and HIPC countries, as well as that obtained when focusing on industrial. The pooled regression relies mostly on between information, so that it replicates the results of the cross section. The fixed effect results, however, focuses on within country volatility. These regressions (except for the industrial subset for which no variable is significant) seem to confirm the results of the cross section that foreign direct investment flows and insurance appear to be related to trade in dark matter.

With these new interpretations in hand we can return to figures $3 \mathrm{a}, 3 \mathrm{~b}$ and make an informal evaluation of the reasons for exports and imports of dark matter. The US appears as a large outlier probably the result of its FDI investments and its unique ability to sell insurance and liquidity services. A Bretton Woods II interpretation makes it particularly prone to be a large exporter. Similarly Switzerland and UK also share some of the attractive feature of the US economy and appear as exporters of dark matter. Japan appears, surprisingly, as importer. This is rather puzzling, in particular because Meissner and Taylor (2006) find Japan to also enjoy a return privilege. Energy producers and FDI recipients: Ireland, Singapur, Venezuela, and Kuwait, all predictably appear as importers of dark matter. More surprising is to find France, Italy and Germany also as importers. While Meissner and Taylor find Italy to have a negative privilege, consistent with these results, they

\footnotetext{
${ }^{25}$ The result for oil producing country is robust to data changes, so it does not respond uniquely to the recent increase in oil prices.
} 
do not find any significant results for Germany and France. Finally Mexico appears as a large exporter of dark matter, something that may be explained through a similar debt relief channel as was argued for Nicaragua, though in this case resulting from its banking crises which wiped out the return of foreign assets acquired prior to the devaluation.

\section{Section IV. A new look at global imbalances}

With a better understanding of what dark matter is, we apply our methodology to the understanding of global imbalances. In order to have a working benchmark Figure 6a presents the official evolution of the net asset position of major global players as a share of world GDP. It shows a world that is increasingly unbalanced with Japan and the rest of the world financing Europe and primarily the US, which appears accumulating a growing external debt. In these graphs the rest of the world is calculated as a residual to make things add up to zero. ${ }^{26}$

The work of Lane and Milesi Ferretti (2001, 2005, 2006) leading to the External Wealth of Nations Database, is an attempt to provide better estimates of net foreign positions. In their initial JIE paper they correct official numbers by adjusting for a series of problems (capital account transfers, debt reductions, exchange rate changes, portfolio equity adjustments, etc). However, to obtain comparability across countries, in that paper FDI was taken at book value. By the time of the 2006 version of their Wealth of Nations database, a large fraction of countries had started publishing reliable market value estimates of their net stock of FDI, so the latter version relies more heavily on this data. But, while they significantly improve on current statistics the main trends are based on official numbers so they do not provide a description that is very different from that of official statistics. Furthermore, because their adjustments of debt assets and liabilities are mostly exchange rate based, even when they find that the US net foreign asset position has been stable in spite of increasing current account deficits in recent years, they conclude that "an important reason why the share of US liabilities in the portfolios of foreign investors has been maintained at a relatively stable level has been the operation of the valuation channel of exchange rate adjustment... it is not a viable long run strategy to rely on such valuation gains to ameliorate a structural reliance on net capital inflows." (Lane and Milesi Ferretti, 2005). Figure 6b shows the same picture as above but with data taken from Lane and Milesi Ferretti (2006). As can be seen the description provided by Lane and Milesi Ferretti is similar to that depicted in official statistics. In both data bases the imbalances appear to be relatively small, but the net asset positions seem to trend for most of them.

Figure $6 \mathrm{c}$ presents an alternative view, using the net asset positions that we construct by capitalizing the net investment income for each country. As can readily be inferred, the world looks quite different once dark matter is taken into account. First and foremost, the US does not appear as a net debtor but as a net creditor and, as mentioned above, its net foreign asset position has remained stable over the last 20 years. Japan, consistent with official data, is a growing creditor, while the European Union and the rest of world are net debtors. Perhaps the most striking feature of Figure $6 \mathrm{c}$ is that, while net asset positions seem to be larger than when measured with official numbers, it shows a world that is surprisingly balanced with relatively little trend for most groups.

\footnotetext{
${ }^{26}$ Lane and Milesi Ferretti (2006) argue that discrepancies are running close to $6 \%$ of world GDP. Here we are assigning all the discrepancy to the ROW.
} 
Figure 7 focuses on a couple of additional important points that have captured the attention in the discussion on global imbalances. One peculiar feature of all the previous figures is that, at least at the level of generality imposed by looking at the data for these large country groupings, the data seems mute to the recurrent crises in emerging economies that have characterized the global financial markets over the last thirty years. This seems to be the case for both official and dark matter inclusive data. The first two panels in Figure 7 show that this is not because the data does not capture the sharp reversals suffered by individual economies. Figure $7 \mathrm{a}$ and $7 \mathrm{~b}$ shows the evolution of net asset stocks for Thailand and Russia, two countries that experienced sharp reversal in capital flows, in 1997 Thailand and in 1998 Russia. As can be seen both datasets capture the reversal and track each other closely in the case of Thailand. The data for Russia also shows the reversal in 1998, though the data including dark matter shows a renewed deterioration in recent years, in spite of increasing measured current account surpluses. The reason for this is the increased payments obtained from foreigner's interests in the oil\&gas industry that are potentially not fully captured in the official accounts. At any rate, if individual crises are captured by the data, the fact that there is no aggregate result indicates that the sharp reversal in capital flows have on average entailed a redistribution of funds among emerging economies, a conclusion that stands in sharp contrast with the idea the capital necessarily flights to international financial centers during crisis times.

Panel $7 \mathrm{c}$ shows the evolution of the net foreign asset position of China. It shows first, that China is still a net debtor. It also shows that China has reduced its debt considerably in recent years and that reduction has been very quick, though the improvement is not as large as is suggested by the official statistics because China remains an important importer of dark matter. Figure 7d shows Europe's net foreign assets, again as percent of GDP. Prior to the launching of the euro both European Union and the Euro countries moved together. But they have dramatically diverged in recent years, with the UK increasing very significantly its exports of dark matter. The recent role of the UK as exporter of dark matter is an interesting finding for future research.

At any rate, the center of the discussion on the sustainability of recent global imbalances has focused squarely on the US current account deficit. As we have seen, over the recent years exports of dark matter are compensating the large current account deficits in the US. So this leads naturally to the question of whether dark matter is something that can be trusted as a way of keeping the net asset position of the US, and the world, stable in the future. In other words, is dark matter sufficiently stable to hold the world together and avoid global financial markets from running into a crisis? This will depend, ultimately, on how steady is the earning power of the assets that make up dark matter.

Typically the answer to this question, particularly when thinking about the 2001-2005 period, was that the US enjoyed capital gains associated with exchange rate fluctuations. But these were viewed as unreliable, as exchange rates can move the other way at no time's notice (Lane and Milesi Ferretti, 2006). Were the US dollar to appreciate, the US would be left not only with a large current account deficit but also with a large capital loss in its net stock of foreign assets, compounding the reversal. However, the exchange rate channel has been discussed by Gros (2006a) and Kitchen (2006), who conclude it is not an important part of the story. In addition the story runs into problems when applied to the 2004/2006 period, where the dollar did not further depreciate relative to the euro, while dark matter kept growing.

There are basically three ways of assessing whether dark matter exports of the US will continue to be present in the future. One is to analyze the underlying reasons for the existence of dark matter and to argue whether they will continue to hold. In fact, we believe our analysis contributes to the debate 
by identifying the reasons why the interest differential exists, moving the debate from focusing, say, on savings to understanding the underlying sources for the large US net investment income. Discussion then should focus on the health of innovation and creativity of the US corporate sector, on the underlying stability of the US economy, or on the role of the dollar as a leading global store of value. In short, to the extent that these fundamentals remain stable so will the interest differential. As global markets explode in size, the differential will act on a larger base, thus leading to increases in dark matter exports.

An alternative is to look at historical evidence. Did other countries enjoy similar differentials in the past? Where these stable? Meissner and Taylor (2006) tackle this question. They analyze the UK at the end of the XIXth century, as well as the US in the post war period. They argue that the evidence points to the fact that yield differentials declined over time, which they use as a cautionary note on the possibility of the US sustaining large differentials in the future. But they also find that thanks to an increase in leverage these differentials are for the US, and were for the UK, fairly stable as a share of GDP. In the case of the UK the process continued up until an abrupt collapse at the outbreak of WWI leaving open the question as to what would have happened if such event had not occurred.

Finally, a third alternative is to look at the time series properties of dark matter stock over recent years. This is done in Figure 8. The stock stands now at over 40 percent of GDP. Since 1982 it has fallen only in 5 years and the largest drop, which took place in 1985, was barely of $1.6 \%$ of GDP. In short it would take an unprecedented deterioration of the value of dark matter to even approximate the net asset position that today worries analysts. ${ }^{27}$ The reasons for the stability of dark matter are several-fold. To the extent that FDI assets abroad continue to rise and to generate excess returns then we should expect to measure continued export of dark matter. If the ability of the US to provide insurance and liquidity services to the rest of the world is based on size and a more stable economy, to the extent that these features persist into the future and that the world economy continues to integrate in trade and financial assets, the US will increase, not decrease its sales of dark matter. In fact, an alternative view could even say that the increasing official current account deficit of the US is the consequence of the rising export of dark matter, which has gone from 1.5 percent of GDP before 2000 to 5 percent of GDP since 2000. It is this source of wealth that funds the booming import bill of the US. To the extent that its underling causes are stable, less should be the worry with the measured imbalances.

\section{Section IV. Conclusions and future research}

In a nut shell our story is very simple. The income generated by a country's financial position is a good measure of the true value of its foreign assets. Once assets are valued accordingly the data seems to indicate that official statistics may provide a distorted picture of current account imbalances. In particular, net asset positions for Japan, Europe the US and the rest of the world seem fairly steady over time. In the specific case of the US, which has drawn substantial attention due to its growing current account imbalances, we find that it has been piling a large amount of net foreign assets that are unaccounted for. These allow the US to have a net income on its foreign asset position making it a net creditor, not a net debtor. This net foreign asset position appears to have been fairly stable over the last 20 years. The difference with the official story probably comes from a

${ }^{27}$ Econometrically one can show that the trend is positive standing at about 2.4\% of GDP for the period 82-05, and strongly statistically significant ( $\mathrm{p}$ of .00019). 
combination of mismeasurement of assets, the unaccounted export of know-how carried out by US corporations through their investments abroad, as well as the sale of insurance and liquidity services. The last three factors relate explicitly to characteristics of the US that cannot be easily replicated elsewhere, and explains why the US looks like a consistently smarter investor, making more money on its assets than it pays on its liabilities. We called the value of these characteristics dark matter shedding a new light on the discussion of the US role in global imbalances. To the extent that dark matter has kept US net foreign assets relatively stable, the discussion on the instability of global imbalance should focus on the sources of dark matter: the stability of the US economy, its role as a cradle for ideas, or the ability that it commands on liquid assets and prudent macroeconomic policies. But these issues have not been the central issues of the debate that have focused mostly on domestic savings or on speculating about the willingness of official creditors to finance the measured imbalances.

However, dark matter also sheds a different light on the often discussed savings puzzle. According to the official statistics, the US appears as a profligate consumer with dismal savings. However, these numbers suggest that the US savings rate may be understated by the amount of dark matter it exports and the savings of the rest of the world overstated by the amount of dark matter it imports. To the extent that there are unreported capital gains, these could be included in the current account and in national accounts, increasing the savings rate and national income ${ }^{28}$. If so it could be argued that the US may have been saving significantly more than accounted by official statistics. Exports of dark matter are perceived by households as a source of income, while the stock of dark matter is a source of wealth. The value of this Dark Matter is reflected in the S\&P500 and the American consumer is appropriating these benefits in their $401 \mathrm{Ks}$ and other asset holdings. Hence, savings could be under reported by the amount of dark matter exports (about $5 \%$ of GDP since 2000). The result is a consumption level that seems inconsistent with measured statistics but that is normal given actual wealth.

Our computation of dark matter leaves open several interesting areas of research. As a starter, we believe it signals on the importance to improve on the estimates of factor income accounting in the balance of payments and its underlying determinants. Alternatively, it would be interesting to look at dark matter by sector and region, to get a better sense of where it is being created and deployed. Likewise while we have somewhat looked into the evolution of dark matter for the US, and briefly for other countries, individual stories are likely to be different and equally interesting. In addition, it should be important to study the stochastic properties of dark matter over time and across countries.

\footnotetext{
28 According to Perozek and Reinsdorf (2002), national income is defined as originating from current production of goods and services, so it excludes capital gains. This is because with capital gains excluded from income, national saving becomes conceptually equal to domestic investment plus net foreign investment. According to these authors when making consumption decisions, households appear to treat capital gains differently from ordinary income, so a measure of income that includes capital gains would not relate as well to consumption as the NIPA concept of income. Also because capital gains tend to be volatile, if included, measures of income or saving would exhibit large fluctuations that would limit their usefulness. Alternatives to the definition of income that is used in the NIPA's are, of course, possible. Haig (1921) and Simons (1938), for example, define income as consumption plus change in wealth, which has the effect of including capital gains. At the opposite pole is Fisher (1906), who identifies income with consumption and treats it as a flow of services rendered by capital. If capital gains were to be included then measures of savings would have been underreported in the case of the US.
} 
To the extent that current account surpluses have to match deficits somewhere else, studying dark matter in some countries can provide clues for adjustments elsewhere. Oil prices, for example, may be an important driver of investment returns in some countries and thus lead to important transfers of dark matter.

Globalization and financial integration have made asset positions all the more relevant. As the gross stock of assets and liabilities increases valuation adjustments on these assets may overshadow the traditional measure of the current account as drivers of the net asset position. As we've seen, flows of dark matter are a very significant part of the story. As a result traditional measures of current account balances will paint an increasingly distorted picture of reality. In particular, they currently point towards imbalances that are not really there, making analysts predict crises that, for good reason, remain elusive. 
References

Barro, Robert (2005), "Rare Disasters and Asset Markets in the Twentieth Century", Mimeo Harvard University.

Blanchard, O., F. Giavazzi and F. Sa (2005) “The US Current Account and the Dollar", NBER Working Paper No. 11137.

Buiter, Willem (2006) "Dark Matter or Cold Fusion?” Goldman Sachs, Global Economics Paper No. 136.

Caballero, R., E. Farhi and P. O. Gourinchas. (2005) "An Equilibrium Model of "Global Imbalances" and Low Interest Rates”, Mimeo MIT, September.

Caves R., J. Frankel and R. Jones (1996) World Trade and Payments, An Introduction, Harper Collins, Seventh Edition.

Cline, W. (2005) The United States as a Debtor Nation, Institute for International Economics, Washington DC.

Cooper, Richard (2005) “Living with Global Imbalances” IIE Policy Brief, October.

Corrado, Carol, Charles Hulten and Daniel, Sichel (2006) Intangible Capital and Economic Growth, Federal Reserve Board, Washington. No. 24

Dooley, Michael, David Folkerts-Landau and Peter Garber (2004) "The Revised Bretton Woods System," International Journal of Finance and Economics, 2004, v9(4,Oct), 307-313., provide alternative stories that are compatible with dark matter.

Eichengreen, Barry (2006) "Global Imbalances: The New Economy, the Dark Matter, the Savvy Investor, and the Standard Analysis" Mimeo March.

Fisher, Irving (1906) The Nature of Capital and Income. New York: Macmillan.

Fixler, Dennis, M. Reinsdorf and G. Smith (2003) "Measuring the Services of Commercial Banks in the NIPAs" Survey of Current Business, September.

Gourinchas P. O. and O. Jeanne (2006) "Capital Flows to Developing Countries: The Allocation Puzzle," Mimeo, University of Berkeley.

Gourinchas P. O. and O. Jeanne (2005) "The Elusive Gains from International Financial Integration "forthcoming Review of Economic Studies.

Gourinchas P. O., and H. Rey (2006) "From World Banker to World Venture Capitalist: US External Adjustment and the Exorbitant Privilege", Clarida, R. (ed.) G7 Current Account Imbalances: Sustainability and Adjustment, The University of Chicago Press, forthcoming. 
Gros, Daniel (2006a) Foreign Investment in the US (I): Disappearing in a black hole? CEPS Working Document No. 242/April.

Gros, Daniel (2006b) Foreign Investment in the US (II):Being taken to the cleaners? CEPS Working Document No. 243/April.

Haig, Robert M. (1921) The Federal Income Tax. New York: Columbia University Press.

Hausmann, Ricardo and Federico Sturzenegger (2005a), .Dark Matter Makes the U.S. Deficit Disappear,. Financial Times (8 December), p. A15.

Hausmann, Ricardo and Federico Sturzenegger (2005b) U.S. and Global Imbalances: Can Dark Matter Prevent a Big Bang? Working Paper, Kennedy School of Government, November.

Higgins, Mathew, Thomas Klitgaard and Cedric Tille (2005) "The income implications of rising US international liabilities", Current Issues in Economics and Finance, Federal Reserve Bank of New York, Volume 11, No. 12, December 2005.

Higgins, M., T. Klitgaard and C. Tille (2006) “Here's What's the Matter with Dark Matter”, Mimeo Federal Reserve Bank of New York.

Ju, Jiandong and Shang-Jin Wei (2006) "A Solution to Two Paradoxes of International Capital Flow”, IMF Working Paper No. 06/178

Kitchen, John (2006) "Sharecroppers or Shrewed Capitalists? Projections of the US current account, international income flows and net international debt". Mimeo, Office of Management and Budget.

Klingen, C., B. Weder and J. Zettelmeyer (2004) "How Private Creditors fared in Emerging Debt Markets, 1970-2000", IMF Working Paper No. 04 /13.

Kozlow, R. (2002) "Valuing the Direct Investment Position in US Economic Accounts" available at http://www.bea.gov/bea/papers/Kozlow-Val.pdf

Kugler, P. and B. Weder (2004) "International Portfolio Holdings and Swiss Franc Returns", Mimeo University of Mainz.

Kugler, P. and B. Weder (2005) "Why are Returns on Swiss Franc Assets so Low? Rare Events May solve the Puzzle, Applied Economics Quarterly.

Landefeld S. and A. Lawson, (1991) "Valuation of the US Net International Investment Position", Survey of Current Business, May, pp. 40-49.

Lane P. and G. M. Milesi Ferretti (2001), “The Wealth of Nations” Journal of International Economics.

Lane P. and G. M. Milesi Ferretti (2005), “A Global Perspective on External Positions”, NBER Working Paper 11589, September. 
Lane P. and G. M. Milesi Ferretti (2006) "The External Wealth of Nations Mark II: Revised and Extended Estimates of Foreign Assets and Liabilities, 1970-2004" IMF Working Paper No. 06/69, Washington.

Lawrence, R. (1990) "US Current Account Adjustment: An Appraisal”, Brookings Papers on Economic Activity, Vol 2. pp. 343-392.

Lawrence, R. and J. Lara (2006) “Trade Performance and Industrial Policy” Mimeo Kennedy

School of Government

Longstaff Francis, The Flight-to-Liquidity Premium in U.S.Treasury Bond Prices Mimeo, UCLA.

Mankiw G. and S. Zeldes (1991) "The Consumption of Stockholders and Nonstockholders" Journal of Financial Economics, 29. pp 97-112.

Mataloni, R. (2000) "An Examination of the Low Rates of Return of Foreign-Owned US Companies” Survey of Current Business, March, pp. 55-73.

McKelvey, Ed. (2005) "Dark Matter in US international Transactions?” Goldman Sachs Economics Research, US Economic Analysis, Issue No. 05/50, December.

Meissner, C. and A. Taylor (2006) "Losing our Marbles in the New Century?

The Great Rebalancing in Historical Perspective," Mimeo LSE.

Milesi Ferretti G. M. (2006) "How Much Progress Has Been Made in Addressing Global Imbalances?", in World Economic Outlook.

Parente, S. and E. Prescott (2002) Barriers to Riches, MIT Press.

Obstfeld, M. (2004) “External Adjustment”, Review of World Economics, Vol. 140 (4).

Obstfeld, M. and K. Rogoff (2000) "Perspectives on OECD Economic Integration: Implications for US Current Account Adjustment" in Federal Reserve Bank of Kansas City, Global Economic Integration: Opportunities and Challenges, March, pp. 169-208.

Obstfeld, M. and K. Rogoff (2005a) The Unsustainable US current account revisited, NBER Working Paper 10864, NBER, Cambridge, MA.

Obstfeld, M. and K. Rogoff (2005b) "Global Current Account Imbalances and Exchange Rate Adjustments” Brookings Papers on Economic Activity, Vol. 1, pp. 67-123.

Perozek M. and M. Reinsdorf (2002) "Alternative Measures of Personal Saving”, Survey of Current Business, April, pp. 13-24. 
Roubini Nouriel and Brad Setser (2004) "The US as a net debtor: The Sustainability of the US External Imbalances" (http://pages.stern.nyu.edu/ nroubini/papers/Roubini-Setser-US-ExternalImbalances.pdf)

Shiller, R. (1993) “Macro Markets: Creating Institutions to manage Society's largest economic riskes". Oxford University Press.

Simons, Henry C. 1938. Personal Income Taxation: The Definition of Income as a Problem of Fiscal Policy. Chicago: University of Chicago Press.

Ulan M. and W. Dewald (1989) "The US Net International Investment Position: Misstated and Misunderstood" in J. Dorn and W. Niskanen (eds.) Dollars, Deficits and Trade, Norwell, MA: Kluwer Academic Publishers.

US Department of Commerce (1990) The Balance of Payments of the United States, Concepts, Data Sources and Estimating Procedures.

Wolf, Martin (2004) “America on the comfortable path to ruin, Financial Times, August 17. 
Figure 1. The Cumulative US Current Account and Net Investment Income (in billions of US dollars)

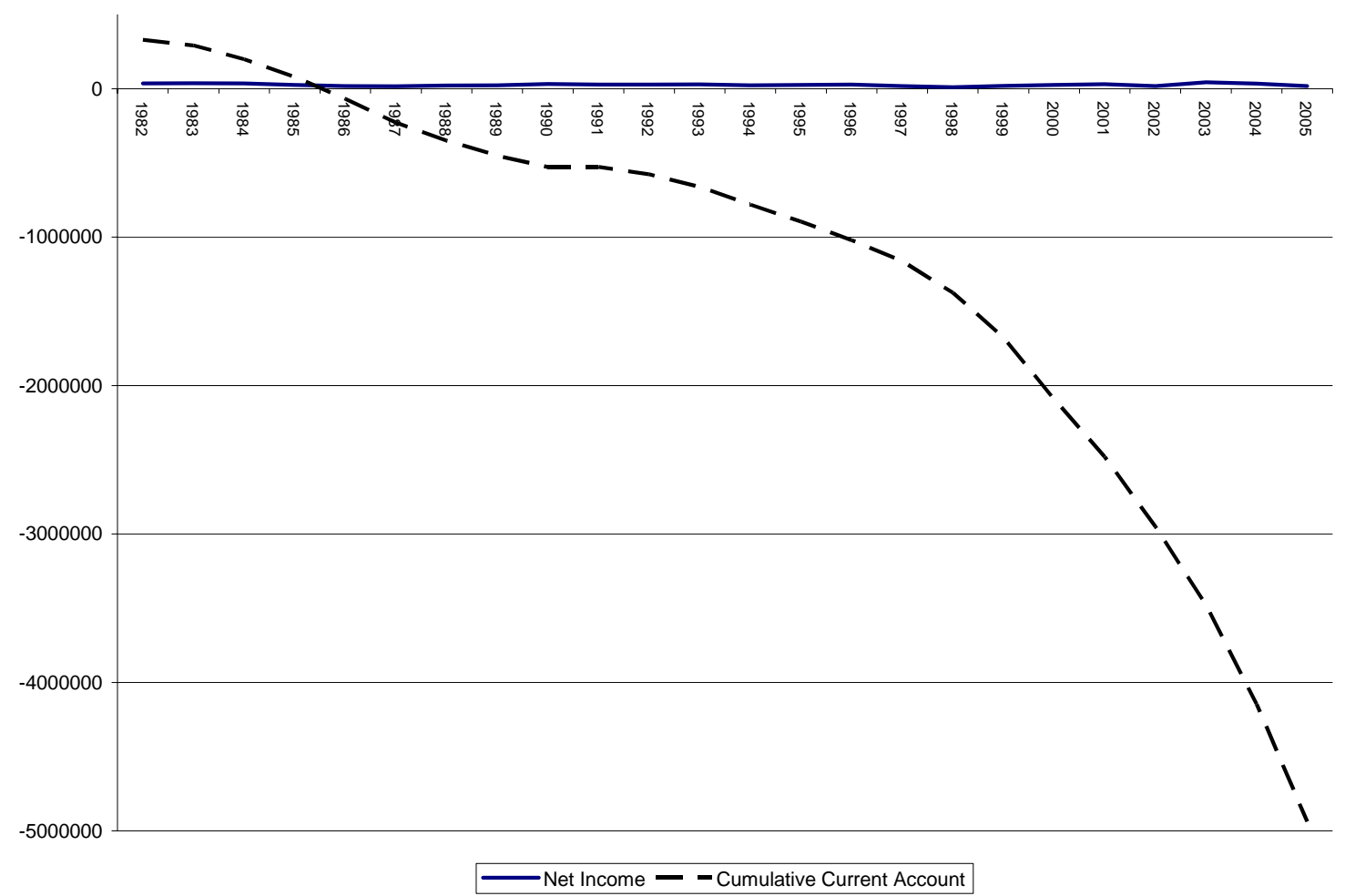

Source: $B E A$ 
Figure 2. The US interest spread 1976-2005

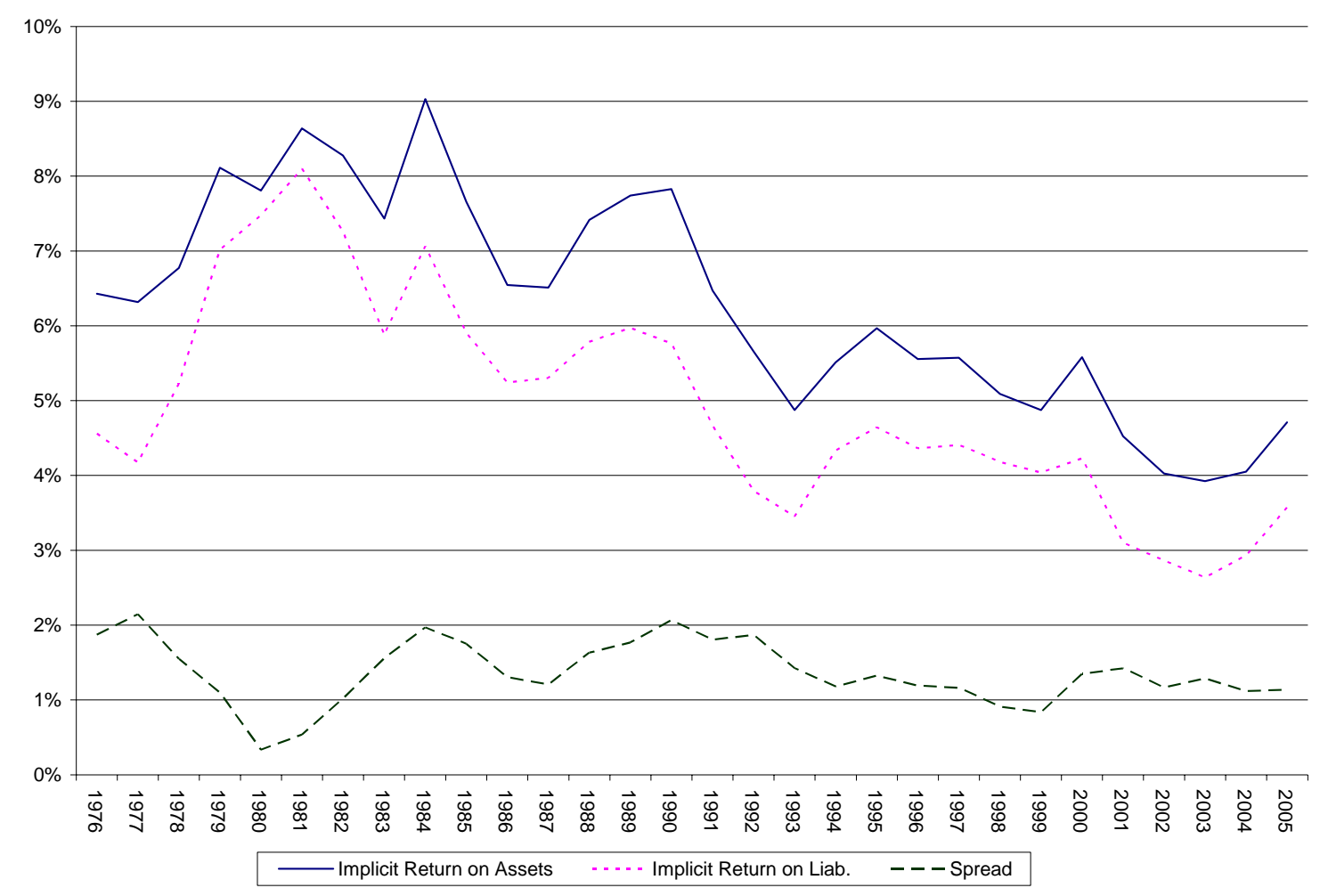

Source: $B E A$ 
Figure 3a. Official Current Account and Change in Net Foreign Assets (1980-2003)

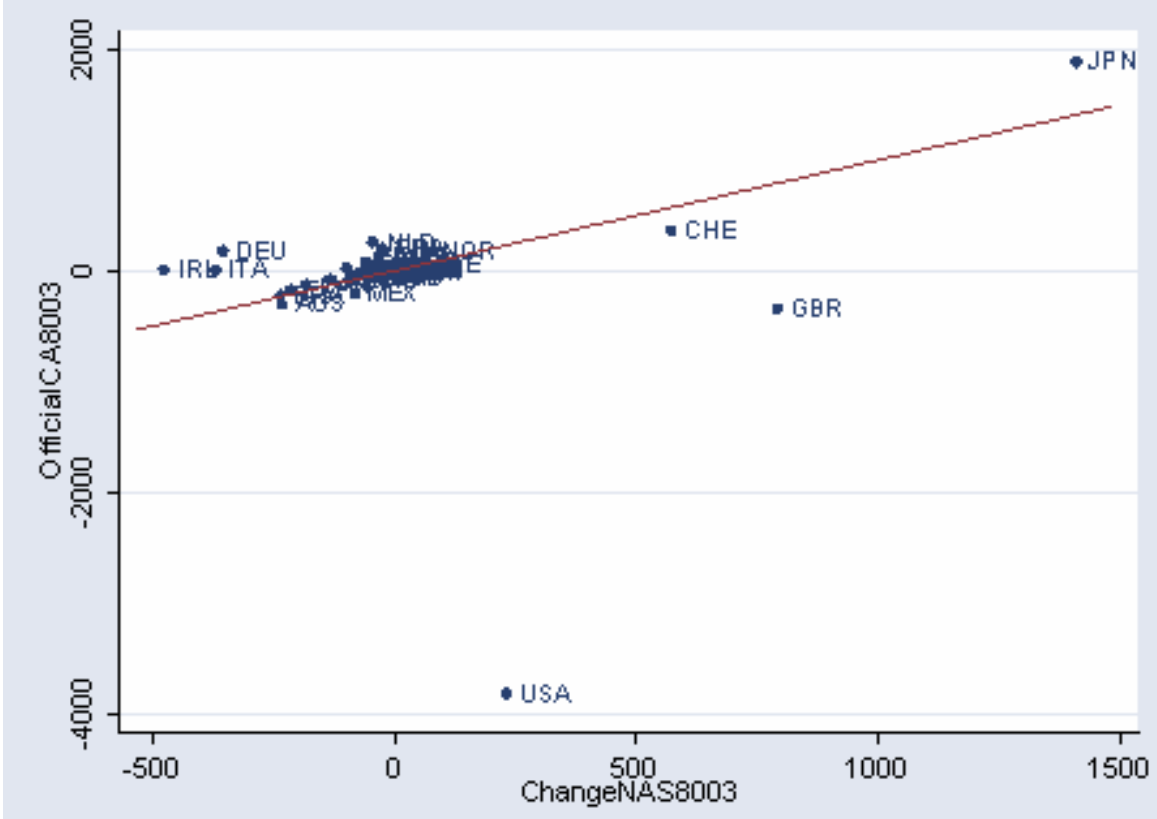

Figure 3b. Official Current Account and Change in Net Foreign Assets (1980-2003)

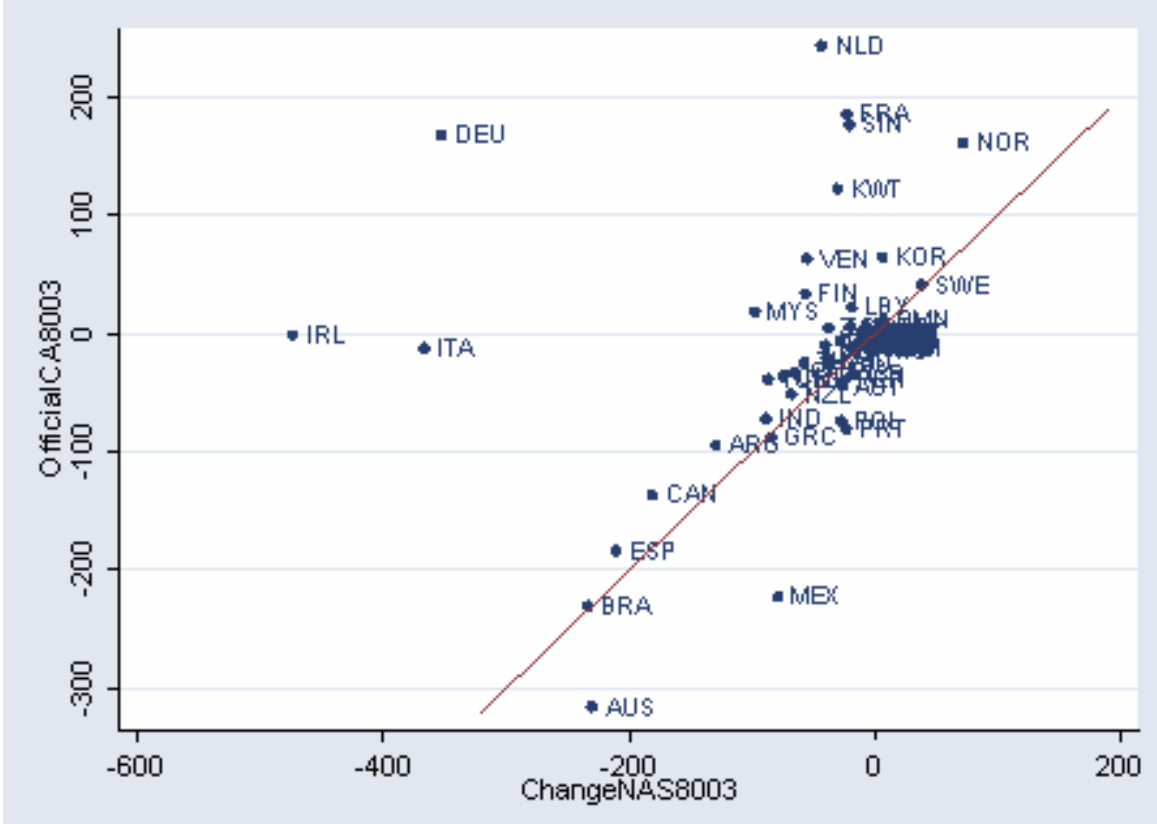

Source: Author's computation on IFS data 
Figure 4. Net Asset Position of the US: BEA, Dark Matter and adjusting FDI by US stock market. In nominal US dollars ('000s)

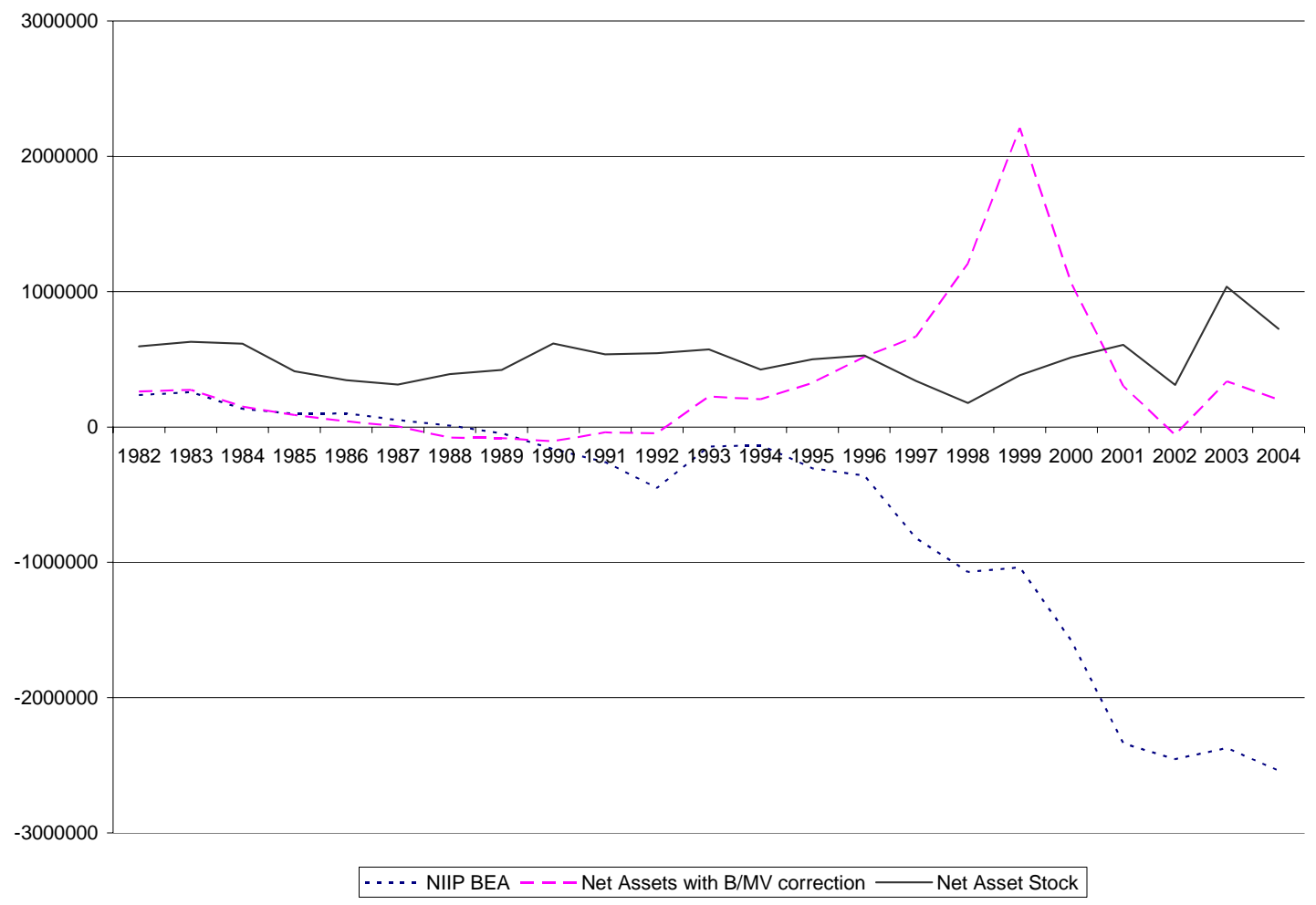

Source: BE $A$ and author's computation using Global Financial Markets Dataset 
Figure 5a. Exports of Dark Matter vs. Official current account (1980-2003) in US dollars

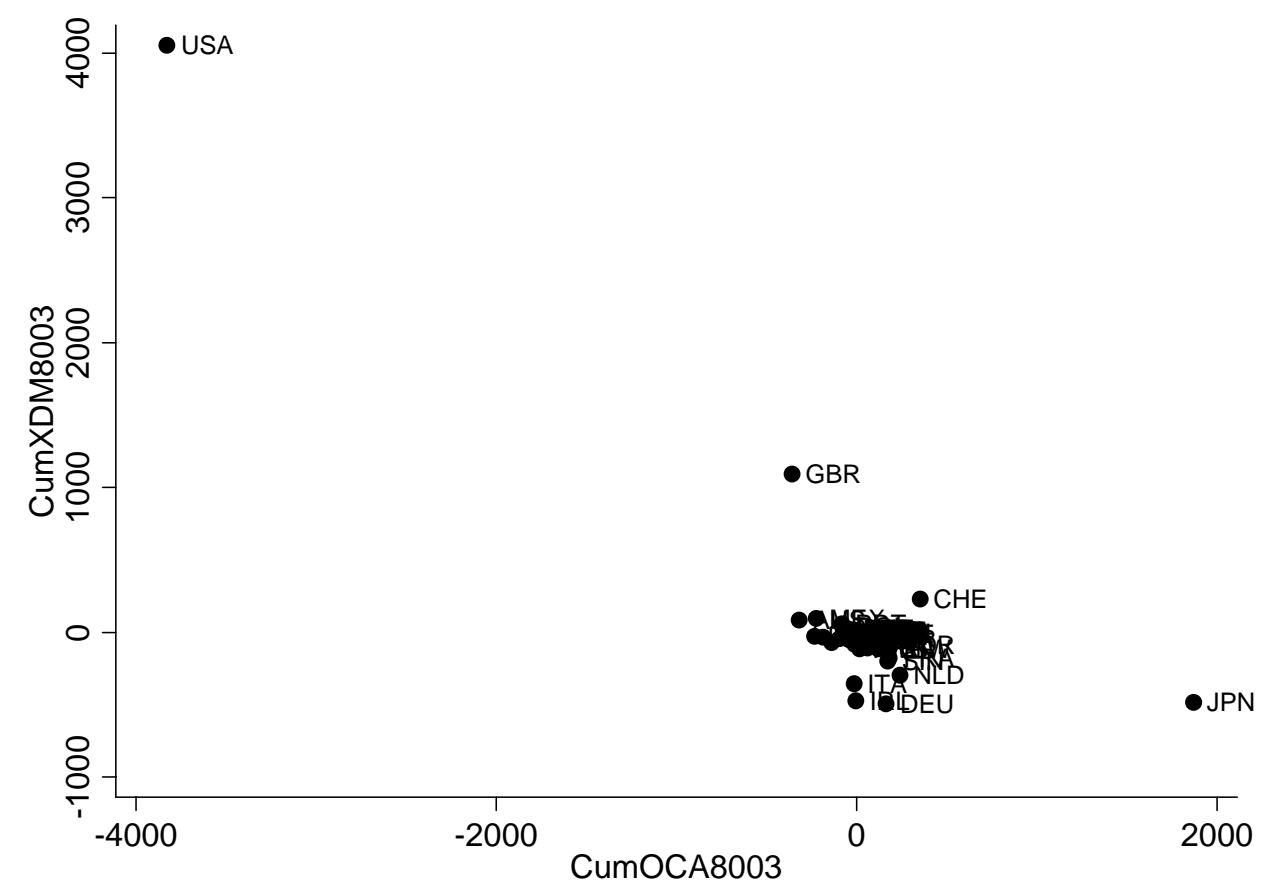

Figure 5a. (cont) Selected countries.

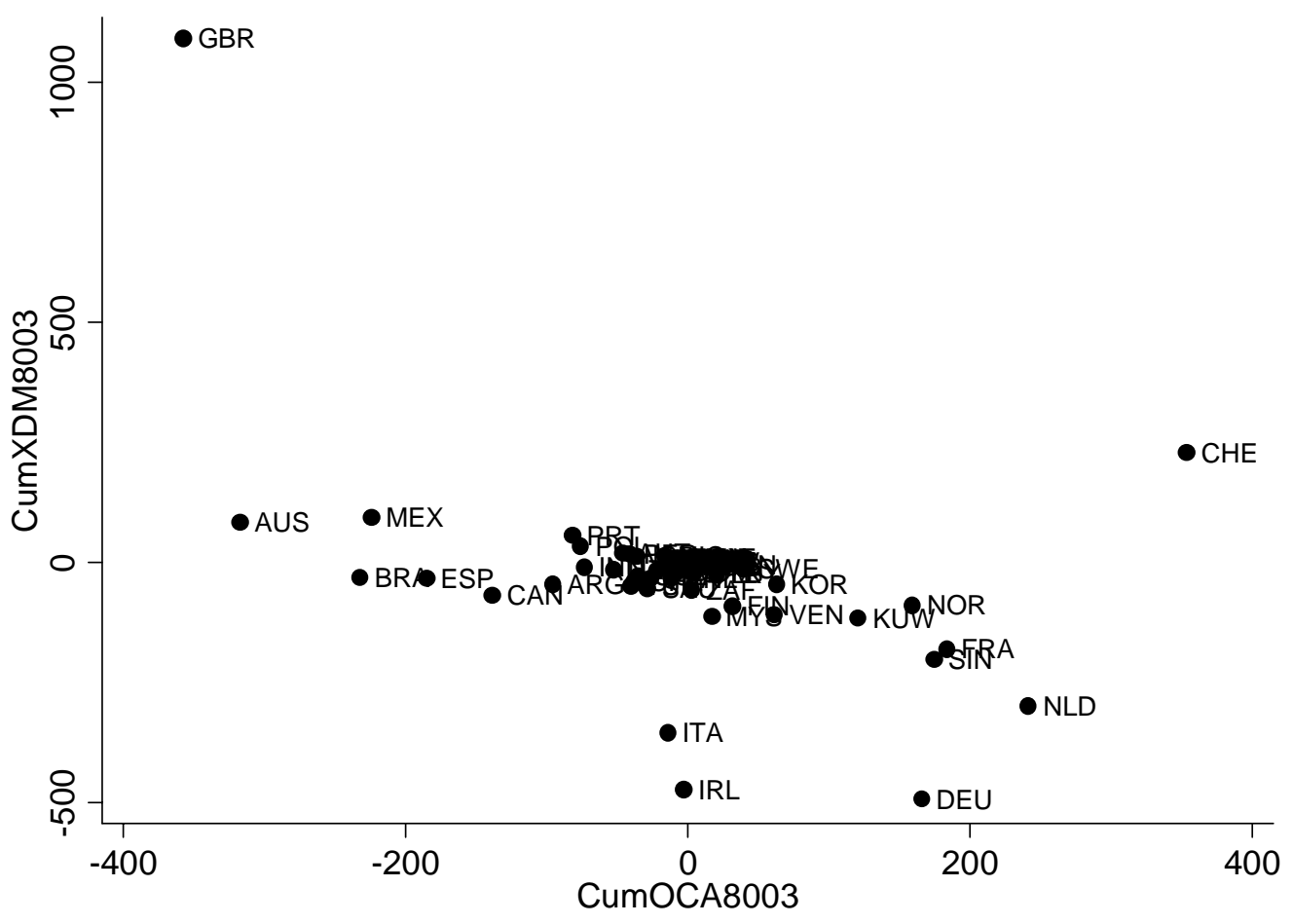


Figure 5b.. Exports of Dark Matter vs. Official current account (1980-2003) as \% of each country's GDP

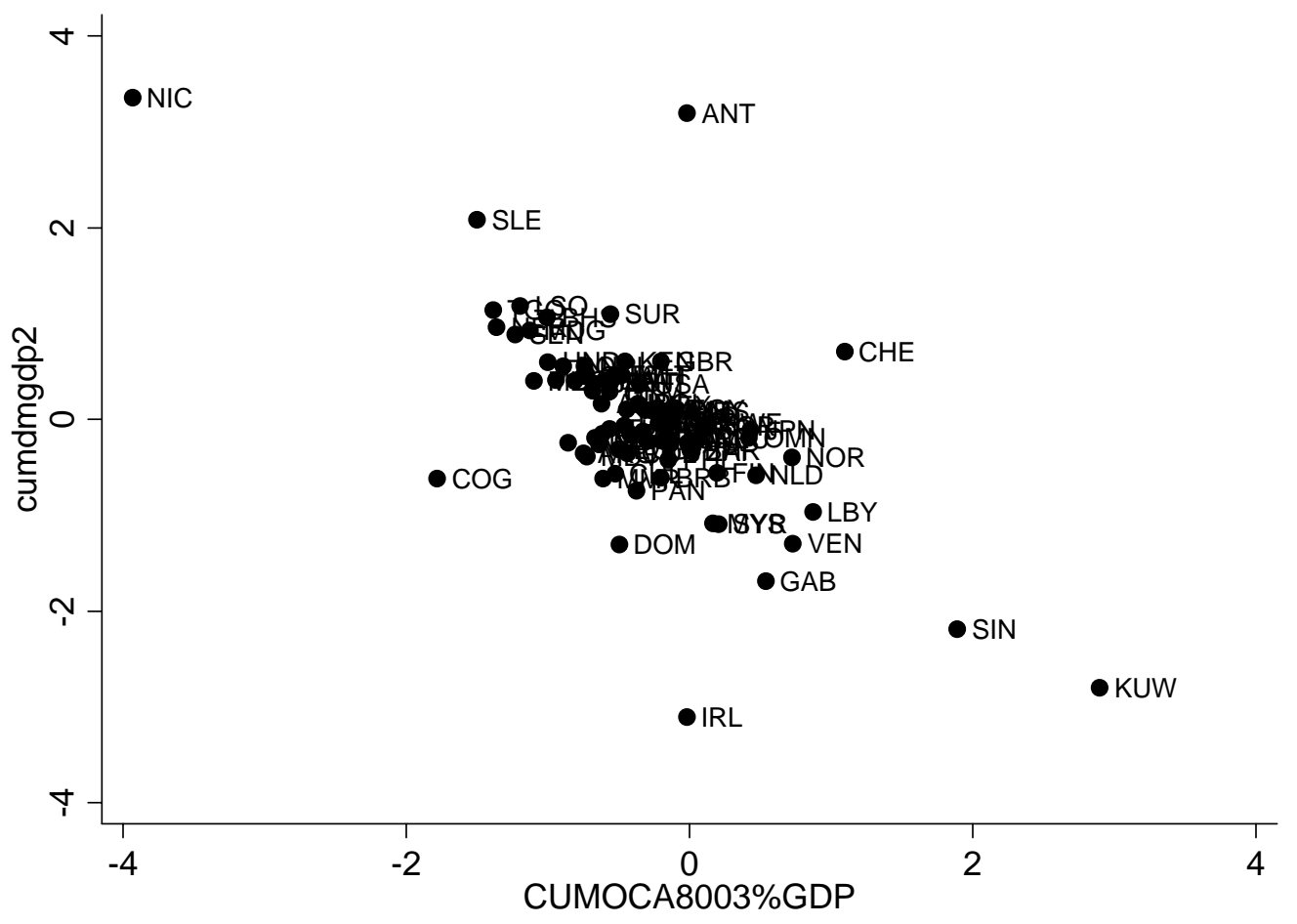


Figure 6a. Net Foreign Assets in the World according to Official Figures (as \% of world GDP)

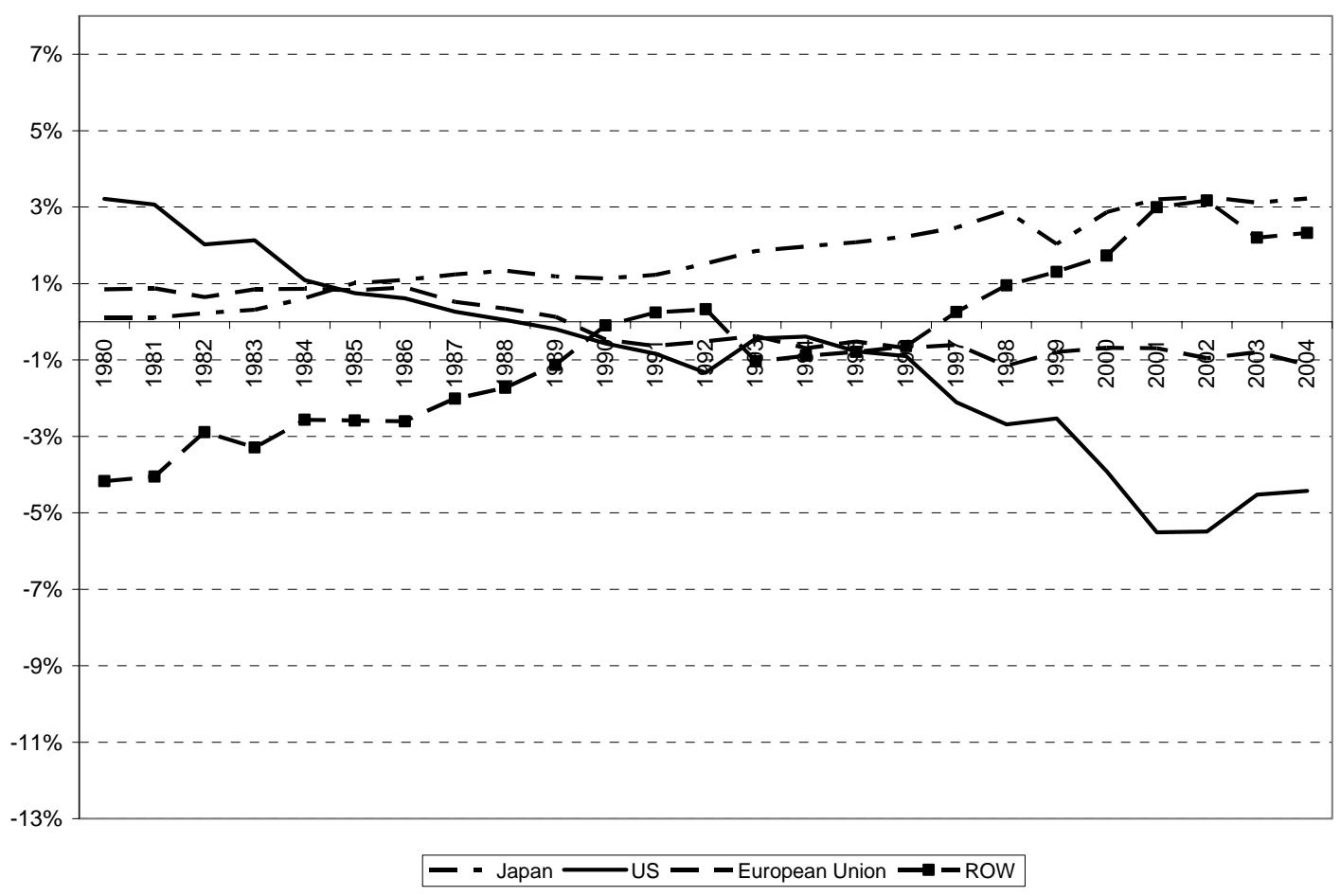

Source: IFS 
Figure 6b. Net Foreign Assets in the World according to Official Figures. Lane and Milesi Ferretti (2006) (as \% of world GDP)

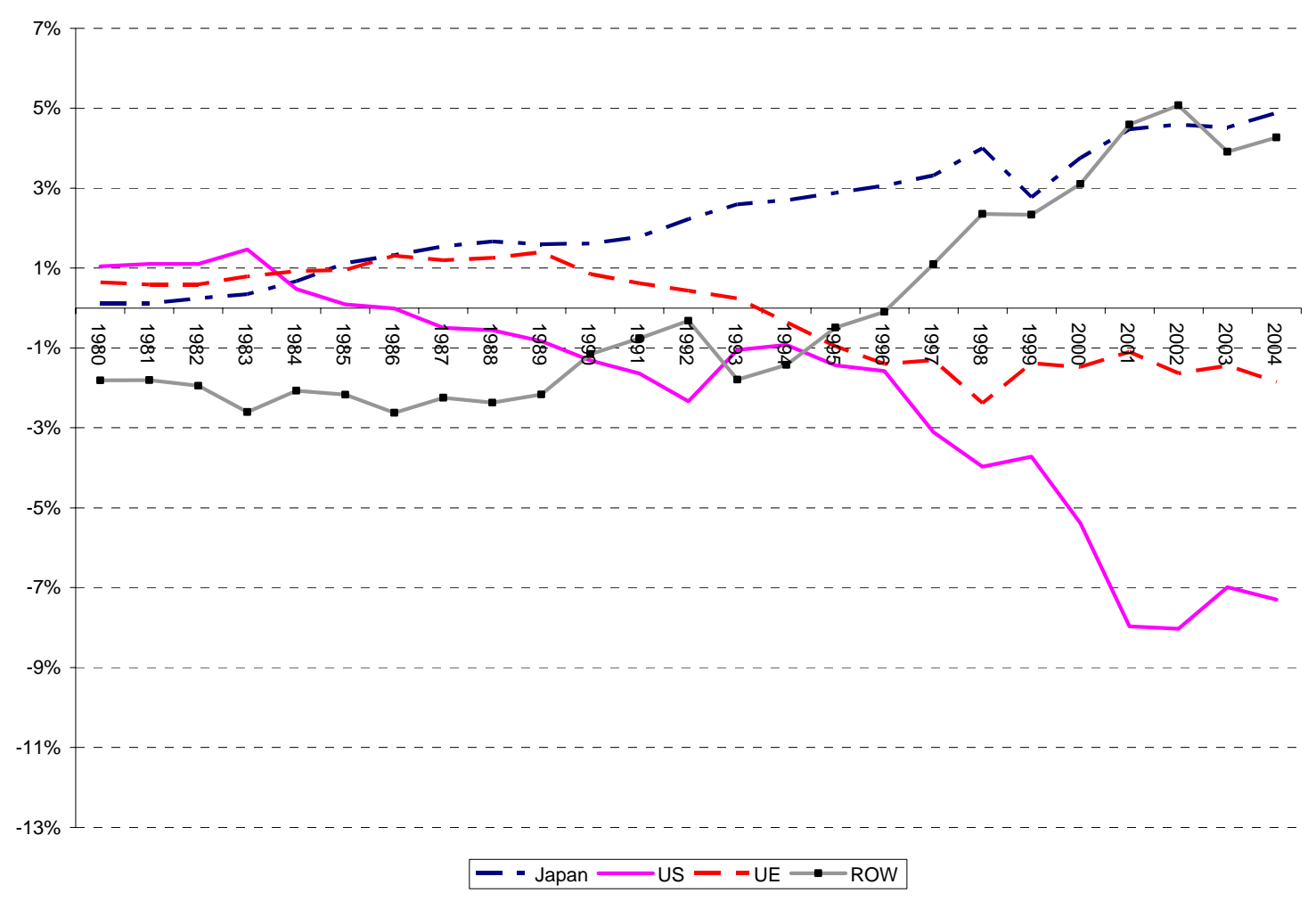

Source: Lane and Milesi Ferretti (2006) 
Figure 6c. Net Foreign Assets taking into account Dark Matter (as \% of world GDP)

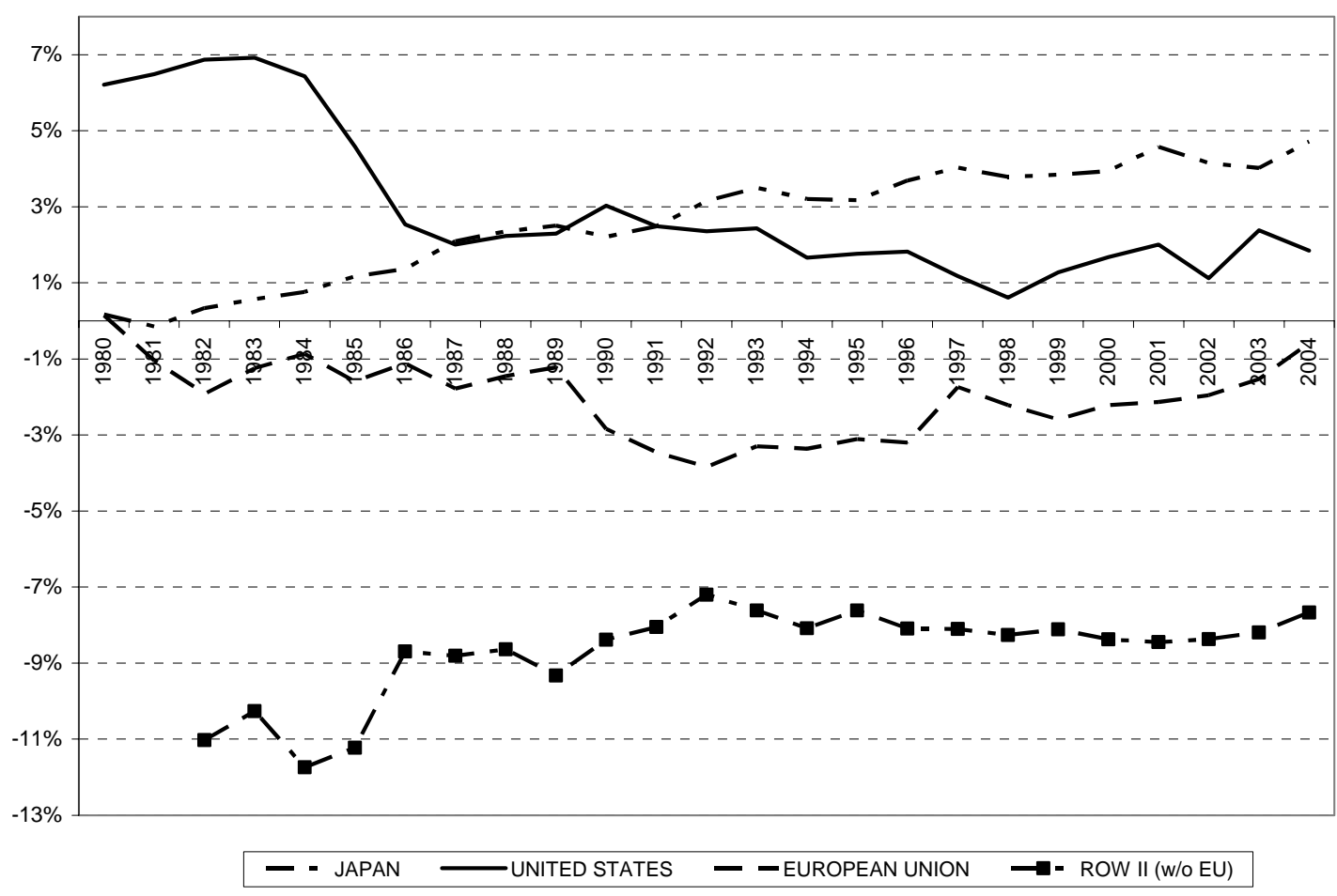

Source: authors' computations on International Financial Statistics data 
Figure 7. Thailand, Russia, China and Europe (in \% of GDP)

(a) Thailand

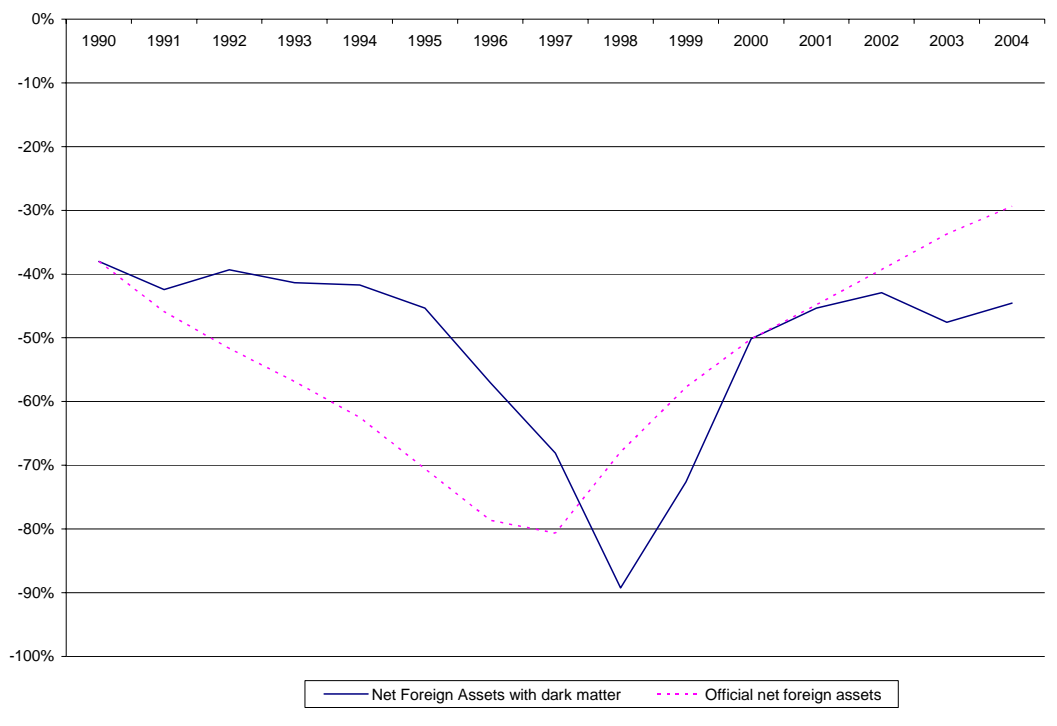

(b) Russia

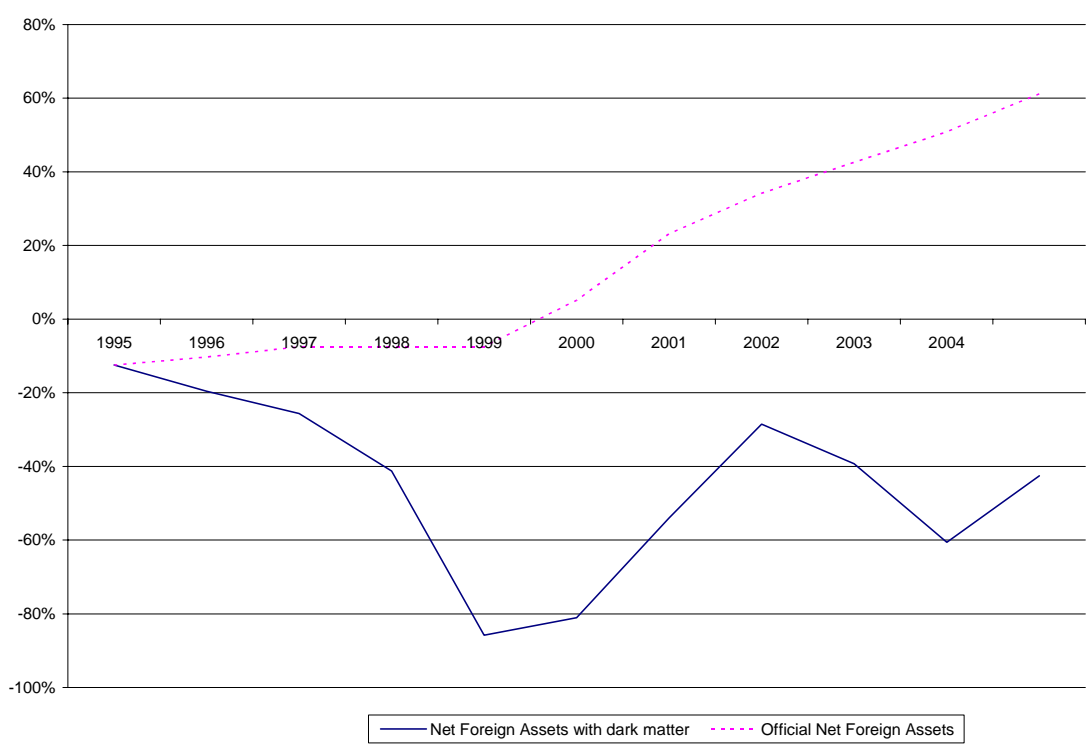




\section{(c)China}

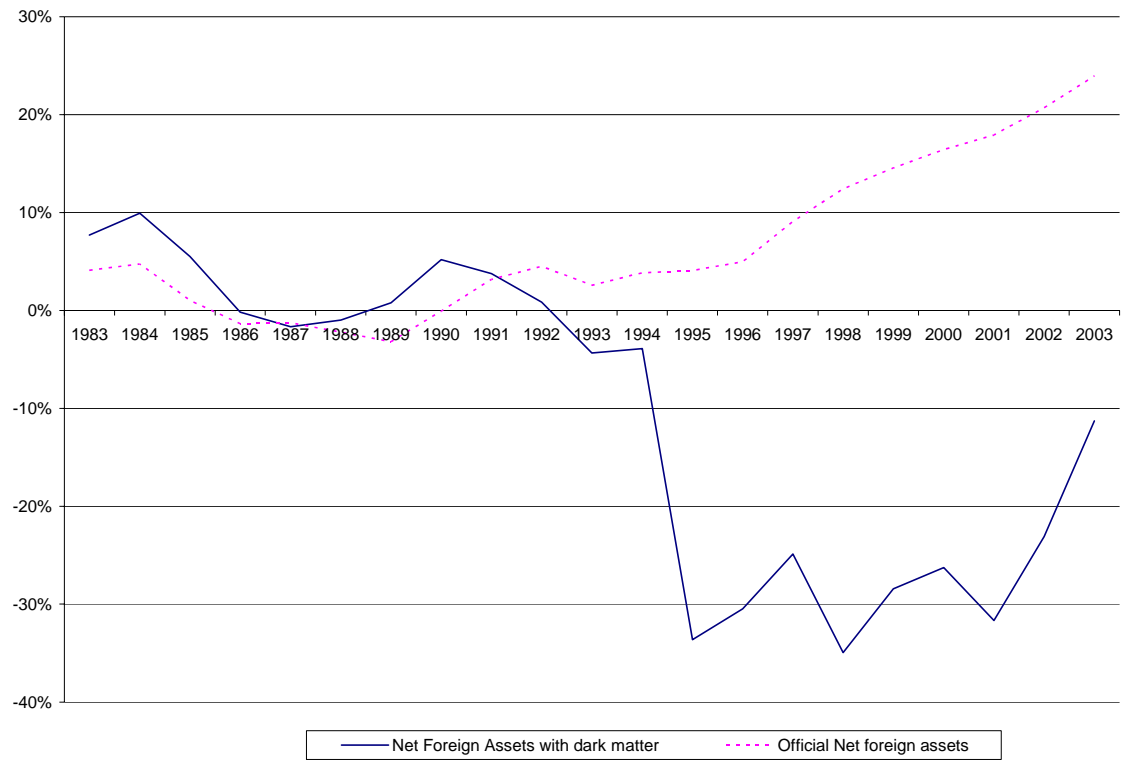

(d) Europe and the European Union

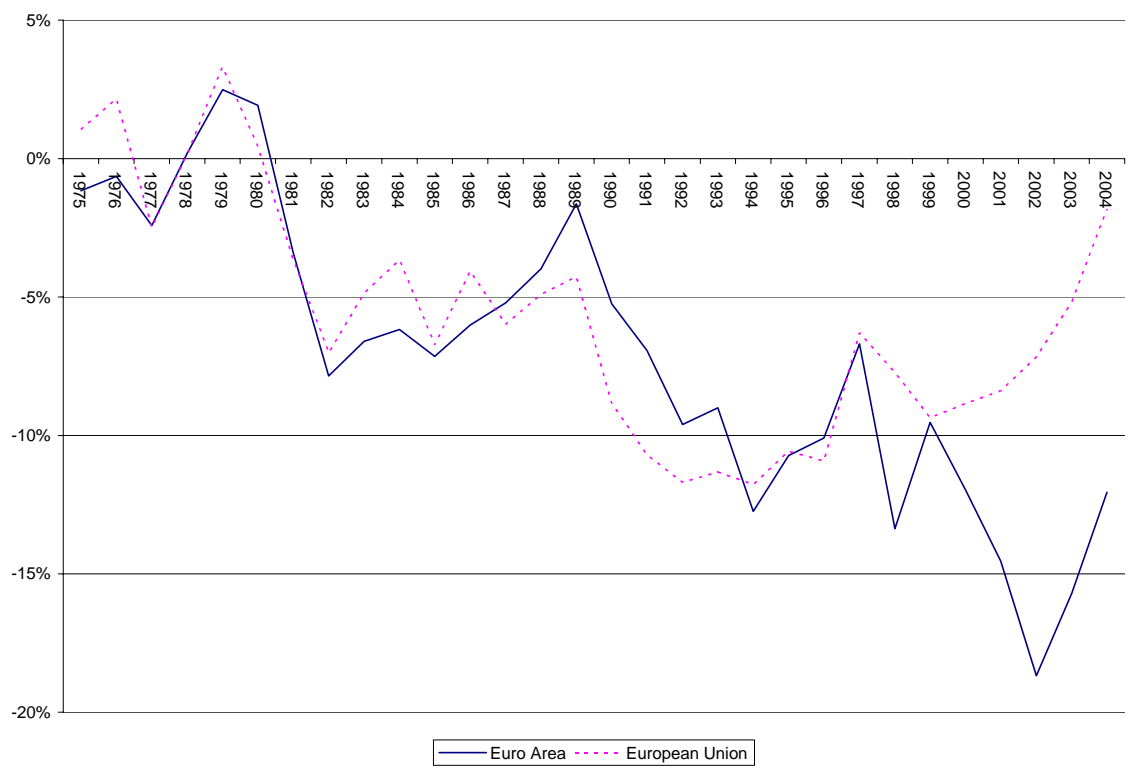

Source: IFS 
Figure 8. US stock of dark matter

(in trillions of US dollars, and in \% of GDP)

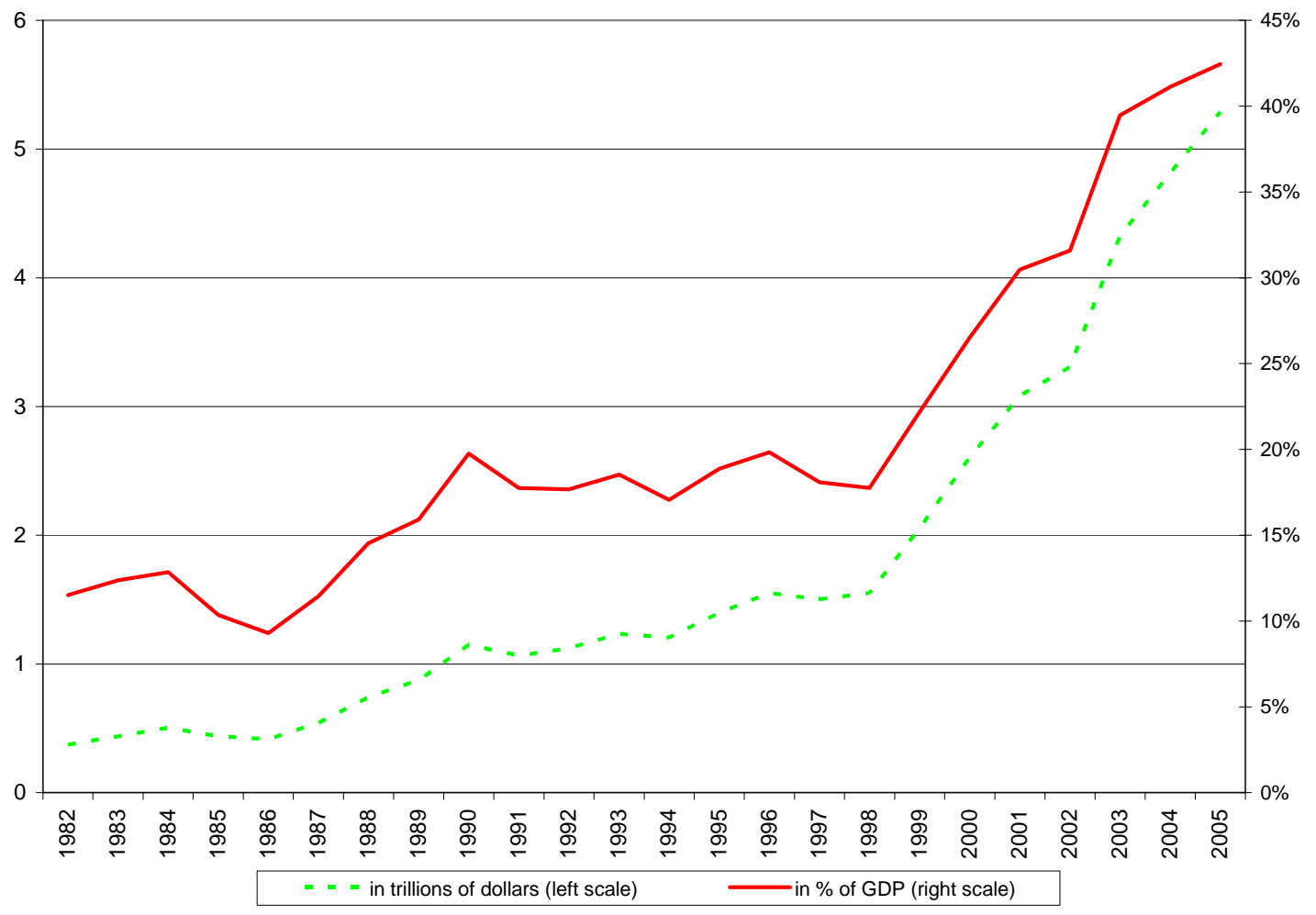

Source: $B E A$ 
Figure B.1. Trading in Contingent assets

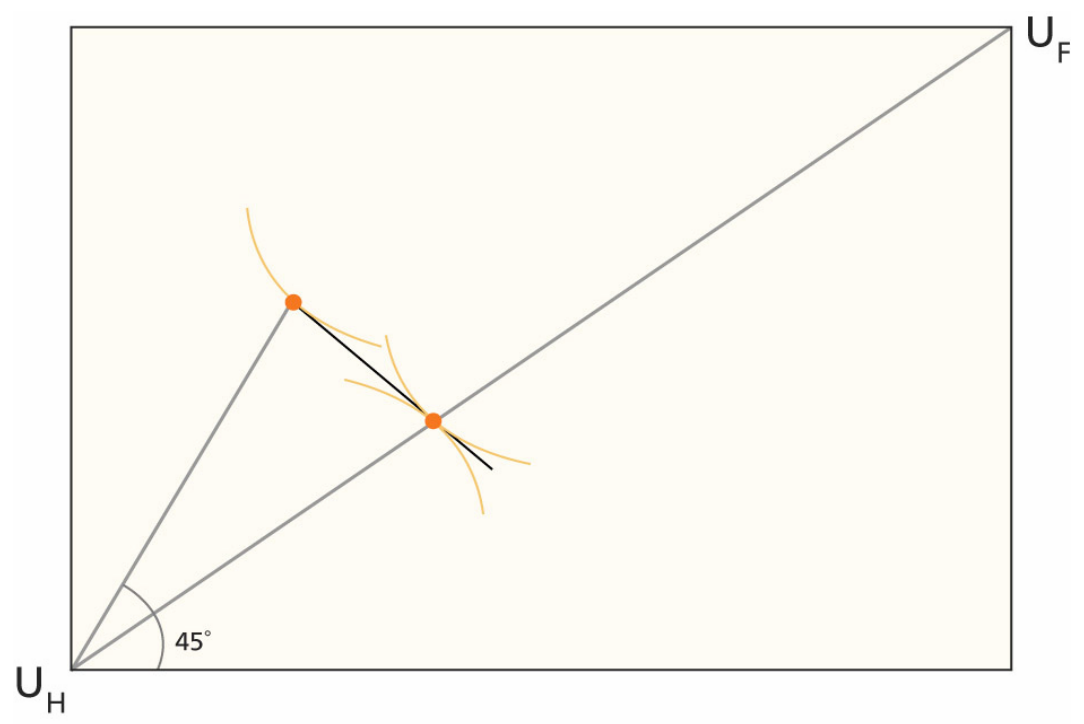

Figure B.2. The infinite risk aversion case

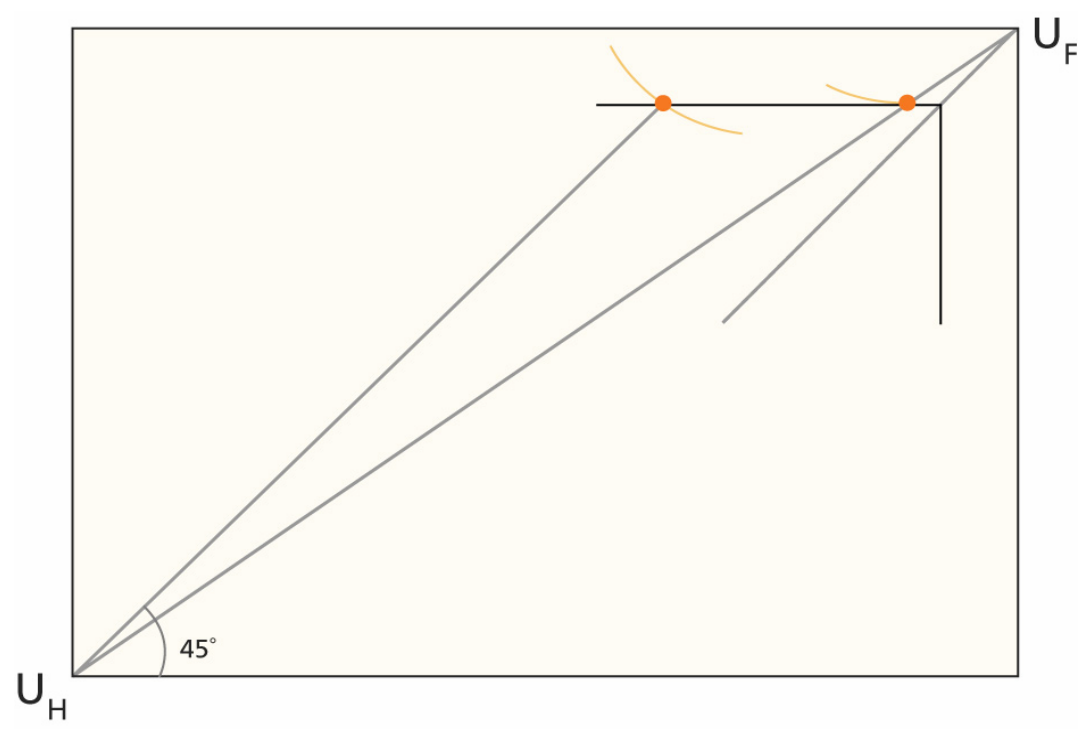


Table 1. Cumulative Official Current Account and its equivalent with dark matter (1980-2003)

Full Sample Excl. US Excl. US \& UK Excl. US \& UK \& JPN

\begin{tabular}{ccccc}
\hline Change in Net Assets w/dark matter & 0.48 & 0.74 & 1.00 & 0.38 \\
& $(2.14)$ & $(9.19)$ & $(16.01)$ & $(5.06)$ \\
Constant & & & & \\
& -28.09 & 15.93 & 30.54 & 5.91 \\
& $(-0.62)$ & $(0.99)$ & $(2.68)$ & $(0.73)$ \\
\hline R-squared & 0.04 & 0.48 & 0.74 & 0.22 \\
\# of observations & 94 & 93 & 92 & 91 \\
T-stats in parenthesis & & & &
\end{tabular}

Table 2. Exports of Dark Matter and the Current account (1980-2003)

\begin{tabular}{lcccc} 
& \multicolumn{3}{c}{ In US Dollars } & In \% of GDP \\
& Full Sample & Excl. US & Excl. US \& UK & Full Sample \\
\hline \multirow{3}{*}{ Cumulative Official CA } & -0.89 & -0.35 & -0.26 & -0.79 \\
& $(19.35)$ & $(-4.90)$ & $(-5.41)$ & $(-8.13)$ \\
& & & & \\
Constant & -4.4 & -18.46 & -31.57 & -0.28 \\
& $(-0.20)$ & $(-1.17)$ & $(-3.02)$ & $(-3.42)$ \\
\hline \multirow{3}{*}{ R-squared } & & & & \\
\# of Observations & 0.82 & 0.22 & 0.26 & 0.43 \\
& 87 & 86 & 85 & 87
\end{tabular}

T-stats in parenthesis 
Table 3a. Relating dark matter exports to fundamentals: cross section

\begin{tabular}{|c|c|c|c|c|c|c|c|}
\hline & (i) & (ii) & (iii) & (iv) & (v) & (vi) & (vii) \\
\hline FDI Asset ( $\%$ gdp) & -0.4 & 0.001 & 0.162 & $(0.52)$ & $(0.24)$ & 0.04 & $1.532 * * *$ \\
\hline & $(0.90)$ & 0.00 & $(0.31)$ & -1.27 & -0.43 & -0.08 & -3.13 \\
\hline FDI Liabilities (\% gdp) & $\begin{array}{c}-0.793^{* *} \\
(2.17)\end{array}$ & $\begin{array}{c}-0.840 * * \\
(2.11)\end{array}$ & $\begin{array}{c}-1.211 * * * \\
(3.57)\end{array}$ & $\begin{array}{c}-0.647 * * \\
-2.11\end{array}$ & $\begin{array}{c}-0.636 * \\
-1.95\end{array}$ & $\begin{array}{c}-0.858 * * * \\
-2.97\end{array}$ & $\begin{array}{c}-2.571 * * * \\
-5.52\end{array}$ \\
\hline Output Volatility & $\begin{array}{c}-11.798^{* *} \\
(2.27)\end{array}$ & $\begin{array}{c}-11.786 * * \\
(2.12)\end{array}$ & $\begin{array}{c}-8.726 * \\
(1.83)\end{array}$ & $\begin{array}{c}-10.935^{* *} \\
-2.53\end{array}$ & $\begin{array}{c}-10.422 * * \\
-2.28\end{array}$ & $\begin{array}{c}-6.881^{*} \\
-1.7\end{array}$ & $\begin{array}{c}(12.70) \\
-0.79\end{array}$ \\
\hline Rule of Law & & $\begin{array}{c}-0.092 \\
(0.64)\end{array}$ & $\begin{array}{l}0.057 \\
(0.43)\end{array}$ & & $\begin{array}{c}(0.08) \\
-0.63\end{array}$ & $\begin{array}{c}(0.09) \\
-0.84\end{array}$ & $\begin{array}{c}0.41 \\
-1.16\end{array}$ \\
\hline Corporate Income Tax rate & & $\begin{array}{l}0.006 \\
(0.56)\end{array}$ & $\begin{array}{l}-0.001 \\
(0.09)\end{array}$ & & $\begin{array}{c}0.01 \\
-1.09\end{array}$ & $\begin{array}{c}0.00 \\
-0.45\end{array}$ & $\begin{array}{r}0.00 \\
-0.12\end{array}$ \\
\hline Spending in $R \& D$ & & $\begin{array}{l}-0.028 \\
(0.19)\end{array}$ & $\begin{array}{c}-0.086 \\
(0.68)\end{array}$ & & $\begin{array}{l}-1.09 \\
0.01 \\
-0.1\end{array}$ & $\begin{array}{c}-0.05 \\
-0.42\end{array}$ & $\begin{array}{l}-0.12 \\
(0.26) \\
-1.53\end{array}$ \\
\hline Dummy for OPEC members & & & $\begin{array}{c}-1.082 * * * \\
(3.50)\end{array}$ & & & $\begin{array}{c}-0.754 * * \\
-2.62\end{array}$ & \\
\hline Dummy for HIPC members & & & $\begin{array}{c}0.783^{* * *} \\
(3.58)\end{array}$ & & & $\begin{array}{c}1.198 * * * \\
-4.94\end{array}$ & \\
\hline Constant & $\begin{array}{c}0.655^{* * *} \\
-2.79\end{array}$ & $\begin{array}{l}0.487 \\
-1.1\end{array}$ & $\begin{array}{l}0.604 \\
-1.62\end{array}$ & $\begin{array}{c}0.571 * * * \\
(2.75)\end{array}$ & $\begin{array}{l}0.208 \\
(0.54)\end{array}$ & $\begin{array}{l}0.235 \\
(0.69)\end{array}$ & $\begin{array}{l}0.312 \\
(0.38)\end{array}$ \\
\hline \# of countries & 79 & 79 & 79 & 99 & 99 & 99 & 21 \\
\hline R-squared & 0.17 & 0.18 & 0.45 & 0.14 & 0.16 & 0.39 & 0.75 \\
\hline
\end{tabular}

Source: IFS, t statistics are shown below each coefficient. *, **, *** indicates significance at 10, 5 and 1\% levels.

Table 4. Relating dark matter to fundamentals: Panel estimation.

Pooled Regressions

Fixed Effects

Full Sample Restricted Sample Industrial Full Sample Restricted Sample Industrial

\begin{tabular}{|c|c|c|c|c|c|c|}
\hline \multirow[t]{2}{*}{ FDI Liabilities ( $\%$ of GDP) } & $-0.146 * * *$ & $-0.176 * * *$ & $-0.309 * * *$ & -0.12 & $-0.147 *$ & -0.093 \\
\hline & -3.3 & -4.08 & -6.47 & -1.46 & -1.71 & -1.1 \\
\hline \multirow[t]{2}{*}{ FDI Assets ( $\%$ of GDP) } & -0.046 & 0.018 & $0.196 * * *$ & -0.043 & 0.012 & 0.076 \\
\hline & -0.78 & -0.32 & -4.36 & -0.39 & -0.11 & -0.97 \\
\hline \multirow[t]{2}{*}{ Volatility of output cycle } & $-0.956 * * *$ & $-0.630 *$ & -0.368 & $-0.945 * *$ & $-0.944 *$ & -0.122 \\
\hline & -2.69 & -1.66 & -0.49 & -2.07 & -1.95 & -0.15 \\
\hline \multirow[t]{2}{*}{ Constant } & $0.050 * * *$ & $0.037 * *$ & 0.012 & $0.045 * *$ & $0.040 *$ & -0.013 \\
\hline & 3.31 & -2.45 & -0.67 & -2.15 & -1.85 & -0.62 \\
\hline Observations & 1624 & 1317 & 439 & 1624 & 1317 & 439 \\
\hline R-squared & 0.01 & 0.02 & 0.09 & 0.01 & 0.01 & 0 \\
\hline \# of countries & & & & 79 & 64 & 21 \\
\hline
\end{tabular}

Source: IFS, $t$ statistics are shown below each coefficient. *, **, *** indicates significance at 10, 5 and 1\% levels. 


\section{A.1 Variable sources}

\begin{tabular}{ll}
\hline \multicolumn{1}{c}{ Variable } & \multicolumn{1}{c}{ Source } \\
\hline & \\
FDI Asset (\% gdp) & Lane \& Milesi Ferretti (2006) \\
FDI Liabilities (\% gdp) & Lane \& Milesi Ferretti (2006) \\
Rgdp volatility & International Financial Statistics \\
Rule of Law & World Bank \\
Corporate Income Tax rate & World Bank \\
Science \& Technology & WDI \\
Dummy for OPEC members & OPEC \\
Dummy for HIPC members & World Bank \\
& \\
\hline
\end{tabular}

\section{A.2 Country lists}

Countries with full data (79): Argentina, Australia, Austria, Bahrain, Bangladesh, Bolivia, Brazil, Canada, Chile, Colombia, Congo, Republic of, Costa Rica, Cyprus, Côte d'Ivoire, Dominican Republic, Ecuador, Egypt, El Salvador, Ethiopia, Finland, France, Gabon, Germany, Ghana, Guatemala, Honduras, Iceland, India, Ireland, Israel, Italy, Jamaica, Japan, Jordan, Kenya, Korea, Kuwait, Libya, Madagascar, Malaysia, Mali, Malta, Mauritius, Mexico, Morocco, Myanmar, Nepal, Netherlands, New Zealand, Nicaragua, Niger, Norway, Oman, Pakistan, Panama, Paraguay, Peru, Philippines, Poland, Portugal, Romania, Saudi Arabia, Senegal, Singapore, South Africa, Spain, Sri Lanka, Sudan, Sweden, Switzerland, Syrian Arab Republic, Thailand, Togo, Tunisia, Turkey, United Kingdom, United States, Uruguay, Venezuela, Rep. Bol.

Countries with some data (109): Albania, Angola, Argentina, Australia, Austria, Bahrain, Bangladesh, Benin, Bolivia, Botswana, Brazil, Bulgaria, Burkina Faso, Cambodia, Cameroon, Canada, Chile, China,P.R.: Mainland, Colombia, Congo, Republic of, Costa Rica, Cyprus, Côte d'Ivoire, Denmark, Dominican Republic, Ecuador, Egypt, El Salvador, Estonia, Ethiopia, Fiji, Finland, France, Gabon, Germany, Ghana, Greece, Guatemala, Haiti, Honduras, Hungary, Iceland, India, Indonesia, Iran, Islamic Republic of, Ireland, Israel, Italy, Jamaica, Japan, Jordan, Kenya, Korea, Kuwait, Lao People's Dem.Rep, Libya, Madagascar, Malawi, Malaysia, Mali, Malta, Mauritius, Mexico, Morocco, Mozambique, Myanmar, Namibia, Nepal, Netherlands, New Zealand, Nicaragua, Niger, Nigeria, Norway, Oman, Pakistan, Panama, Papua New Guinea, Paraguay, Peru, Philippines, Poland, Portugal, Romania, Rwanda, Saudi Arabia, Senegal, Singapore, South Africa, Spain, Sri Lanka, Sudan, Swaziland, Sweden, Switzerland, Syrian Arab Republic, Tanzania, Thailand, Togo, Trinidad and Tobago, Tunisia, Turkey, Uganda, United Kingdom, United States, Uruguay, Venezuela, Rep. Bol., Yemen, Republic of, Zimbabwe.

Same as above but excluding 10 poorest (99): Albania, Angola, Argentina, Australia, Austria, Bahrain, Bangladesh, Benin, Bolivia, Botswana, Brazil, Bulgaria, Cambodia, Cameroon, Canada, Chile, China,P.R.: Mainland, Colombia, Congo, Republic of, Costa Rica, Cyprus, Côte d'Ivoire, Denmark, Dominican Republic, Ecuador, Egypt, El Salvador, Estonia, Fiji, Finland, France, Gabon, Germany, Ghana, Greece, Guatemala, Haiti, Honduras, Hungary, Iceland, India, Indonesia, Iran, Islamic Republic of, Ireland, Israel, Italy, Jamaica, Japan, Jordan, Kenya, Korea, Kuwait, Lao People's Dem.Rep, Libya, Malaysia, Malta, Mauritius, Mexico, Morocco, Mozambique, Myanmar, Namibia, Netherlands, New Zealand, Nicaragua, Nigeria, Norway, Oman, Pakistan, Panama, Papua New Guinea, Paraguay, Peru, Philippines, Poland, Portugal, Romania, Saudi Arabia, Senegal, Singapore, South Africa, Spain, Sri Lanka, Sudan, Swaziland, Sweden, Switzerland, Syrian Arab Republic, Tanzania, Thailand, Trinidad and Tobago, Tunisia, Turkey, United Kingdom, United States, Uruguay, Venezuela, Rep. Bol., Yemen, Republic of, Zimbabwe

Industrial countries (21): Australia, Austria, Canada, Denmark, Finland, France, Germany, Greece, Iceland, Ireland, Italy, Japan, Netherlands, New Zealand, Norway, Portugal, Spain, Sweden, Switzerland, United Kingdom, United Status. 